\title{
COMMENTS
}

\section{POSNERIAN JURISPRUDENCE AND ECONOMIC ANALYSIS OF LAW: THE VIEW FROM THE BENCH}

\section{GeOrge M. Cohen ${ }^{\dagger}$}

Judge Richard A. Posner, of the United States Court of Appeals for the Seventh Circuit, is a renowned scholar in the field of law and economics. Since his appointment to the bench, on December 4, 1981, Judge Posner has had an opportunity to apply in his opinions some of the theories he has so forcefully propounded in his numerous books and articles. ${ }^{1}$ Posner's innovative methodological approach has won him widespread fame and criticism and has made him a top contender for nomination to the Supreme Court during President Reagan's second term. $^{2}$ The simple yet powerful idea that drives Posner's theories is that economic ${ }^{3}$ analysis is a valuable tool for understanding, interpreting, and creating law.

An examination of Posner's judicial work affords an unprecedented opportunity to evaluate the usefulness of economic analysis in judicial decisionmaking. Posner's opinions demonstrate some of the strengths and limitations of the economic analysis of law as a jurisprudential methodology.

More importantly, an examination of Posner's opinions reveals

† B.A. 1982, Yale University; J.D. Candidate, Ph. D. Candidate (Economics), 1987, University of Pennsylvania. The author wrote this Comment while a student at the University of Pennsylvania Law School.

1 See Samuels \& Mercuro, Posnerian Law and Economics on the Bench, 4 INT'L REv. L. \& ECON. 107 (1984) (analyzing Posner's application of the wealth-maximization principle in his first 120 opinions). Posner is a prolific writer, both on and off the bench. As of December 1984 he had authored approximately 247 appellate decisions, 12 books, and over 100 articles. See Crovitz, Winds of Change on the Bench, Wall St. J., Mar. 15, 1985, at 24, col. 4. The influence he wields is no less considerable. On average, each of his decisions has been cited four times; overall, his opinions have been used as precedent in approximately 1,000 cases. See $i d$.

2 See, e.g., Ridgeway, Justice Beware: Best Bets for a Reagan Supreme Court, Village Voice, Oct. 9, 1984, at 12, col. 3; Caplan, Is the Supreme Court Ready for This Kind of Free-Market Justice?, Washington Post, Sept. 30, 1984, at D1, col. 3.

3 Throughout this Comment, the terms "economics" and "economic" will be used to refer to neoclassical microeconomic analysis and theory. Although alternative schools of economic thought, such as Marxist economics, may possibly lay claim to the title "economics," little confusion should arise from this simplification, which is common in contemporary economic literature. 
that Posner as a judge has not been a responsible role model for the use of economic analysis in judicial reasoning. Judges interested in promoting economic methodology as a useful jurisprudential approach would take pains to separate the methodology from political ideology in order to demonstrate the methodology's general applicability. Furthermore, such judges would not use the methodology in ways that stretch beyond its capabilities. Cautious and conscientious application would be their goals.

Yet Posner has violated these ideals. He has applied economic analysis selectively and incompletely; he has used his unique position as the intellectual force behind the law-and-economics movement to support his conservative political ideology; and he has written many opinions as if economic analysis necessarily led to his conclusions. ${ }^{4}$

This Comment analyzes Judge Posner's first three years on the bench by examining both the application of economic analysis in his opinions and the value of this analysis generally for judicial decisionmaking. Part I outlines the basic theoretical elements of Posner's economic analysis. Part II examines some of the more interesting and controversial cases in which Posner has put his economic analysis into practice. Part III uses these cases and others to illustrate specific criticisms of Posnerian jurisprudence. Part IV discusses the proper judicial role for the economic analysis of law.

\section{Elements of Posner's Economic Analysis}

\section{A. The Competitive Market and Efficiency}

Neoclassical price theory, or microeconomics, ${ }^{5}$ provides the foundation for Judge Posner's economic analysis. This body of thought attempts to analyze and predict social behavior by focusing on two simple

- Economic analysis need not be coupled with conservative political views. See infra text accompanying notes 189-92; see also Ackerman, The Marketplace of Ideas, 90 YALE L.J. 1131, 1138-39 (1981) (Economic analysis can be used for radical legal analysis.); Williamson, Intellectual Foundations: The Need for a Broader View, $33 \mathrm{~J}$. LEGAL EDUC. 210, 211-12 (1983) (noting differences in approach by theorists in the law-and-economics field); $c f$. P. SAmuelson, Economics 633-35 (10th ed. 1976) (Principles of welfare economics can be used to support varying conclusions.).

s Microeconomics is the study of how individual consumers and firms, acting through the competitive market, determine prices. Macroeconomics, on the other hand, is the study of the effect of aggregate supply and aggregate demand on the general price level and on the level of national income. See, e.g., P. SAmuesson, supra note 4, at 205, 379-80. For a general explanation of the foundations of neoclassical microeconomics, see R. Russell \& M. Wilkinson, Microeconomics: A SYNTHEsis of Modern and Neoclassical Theory, at ix (1979). This Comment refers most frequently to Samuelson's text, primarily because of the book's popularity and accessibility; however, any good introductory economics text would contain similar material. 
hypotheses. The first hypothesis is that resources are scarce in relation to people's desires to consume them. As a result, people must make choices between various resources or activities. Economists refer to "such choices as "tradeoffs."

The second hypothesis underlying price theory explains how individuals make such tradeoffs. Economic theory maintains that people behave rationally when making decisions; for example, given a choice between a smaller and larger number of goods at the same price, people generally prefer the larger number. In economic terms, people choose resources in a manner that maximizes their personal "utility." This hypothesis generates the law of demand: when the price of a good increases, people will consume less of it. Gonversely, a decrease in price leads to an increase in consumption. ${ }^{7}$ The hypothesis that consumers act to maximize their utility is paralleled by the hypothesis that producers act to maximize their profits. This hypothesis of profit maximization generates the law of supply: when the price of a good increases, producers will supply more of it. The inverse is also deemed true. $^{8}$

- See P. SAmuelson, supra note 4, at 18-23. The situation of a motorist provides an example of this effect. The motorist would like to get to her destination as quickly as possible; time is a scarce resource, and the motorist would like to spend some of her time engaged in activities other than driving. The motorist would also like to avoid having an accident or getting a speeding ticket, however, because her ability to pay for the damages or the ticket is limited. The motorist must therefore choose a speed at which to travel by trading off travel time against the risk of an accident and the risk of being ticketed. In the jargon of economics, the "opportunity cost" of increased speed and less travel time is the higher risk of an accident or a speeding ticket. Opportunity cost in general is the benefit foregone from employing a resource for one use rather than the next best use of the resource. See id. at 474-75.

This example supports Posner's contention that many legal problems can be analyzed by using economics. Legislators and judges consider the same kinds of tradeoffs, albeit from a different perspective, when deciding what speed limit to set and what activities constitute negligent driving.

7 Thus, economic theory suggests that if a state increased its fines for speeding fewer motorists would speed. This concept is known as "the law of downward-sloping demand." See id. at 61.

The law of demand does not always hold true, however. A price increase has two separate effects. The first is the "substitution effect," which means that other goods become relatively cheaper and will be substituted for the good whose price has risen. The second is the "income effect," which means that when the price of a good goes up a consumer's true income declines, and the consumer therefore buys less of all goods. Furthermore, there exist in the economy "inferior goods," such as certain staple foods, which consumers demand in greater quantities when their incomes fall. If the price of an inferior good rises, consumers may end up consuming more of that good if the income effect is strong enough. This case, however, is rare. See id. at $436-37$ \& n.6.

- This "law" is subject to an exception for inferior goods, see supra note 7, as well as to other, more common exceptions. In fact, it is rarely referred to as a law, but rather as the most common relationship between supply and price. See P. SAMUELSON, supra note 4 , at $62-63$. 
From these two hypotheses, economic theory derives its major conclusion about social behavior: under competitive conditions, free trade among individuals will result in a socially optimal allocation of resources. Economic theory defines a "socially optimal allocation" as one in which no individual can better her position without hurting the position of at least one other individual. Such an allocation is said to be "Pareto efficient" or "Pareto optimal."

Despite its conceptual appeal, Pareto efficiency is an incomplete criterion of social welfare. Suppose a proposed reallocation of resources would make some people better off and some people worse off. Even if the new allocation makes one million people better off and only one person worse off, Pareto efficiency does not identify which allocation is preferable. ${ }^{10} \mathrm{~A}$ more serious problem with the criterion is that it uses the status quo as its point of comparison without assessing the justness of the initial allocation. For instance, suppose that in a two-person society one person has all of the resources and the other has nothing. This grossly inequitable allocation is nonetheless Pareto efficient: the only way to better the position of the disadvantaged person is to take some resources away from the advantaged person and thus to make the advantaged person worse off.

Even with these limitations, Pareto efficiency remains a useful concept; indeed, it is the basis of normative economics. ${ }^{11}$ The competitive conditions under which Pareto efficiency is achieved are known collectively as "perfect competition"; deviations from these conditions are called "market failures." An idealistic benchmark, rather than a realistic description of the economy, perfect competition characterizes an economy with a large number of buyers and sellers in each market, ${ }^{12}$ a standardized commodity within each market, relevant market information available to all buyers and sellers, and no transaction

9 Efficiency is therefore a technical economic term for a very specific criterion of social welfare. See generally C. Ferguson \& J. Gould, Microeconomic Theory 439, 465 (4th ed. 1975) (defining the concept of Pareto optimal allocations).

10 Economists circumvent this problem somewhat in their use of the compensation criterion in cost-benefit analysis. See infra text accompanying notes 32-36.

11 See P. Samuelson, supra note 4, at 43-47.

12 In economic terms, a "market" is not a physical entity; rather, it describes the buying and selling of a good within the economy. The requirement that there be a "large" number of buyers and sellers results from the necessity that prices be determined by the market as a whole and not by individual market participants. If any buyers or sellers are powerful enough to affect prices, then the market will not generate an efficient allocation of resources. See generally R. Russell \& M. WiLkinson, supra note 5, at 251-99 (discussing markets characterized by relatively few buyers or sellers); P. SAMUelson, supra note 4, at 43 (discussing the notion of "perfect competition" and the effect of monopolistic imperfections). 
costs. ${ }^{13}$ If these conditions all hold, and if no externalities are present, ${ }^{14}$ then a competitive equilibrium will result: ${ }^{15}$ there will be a set of prices, one for each good, at which the supply of each good exactly equals the demand. ${ }^{16}$ Although real-world markets only approximate competitive-equilibrium allocations, these allocations are important conceptually because they are always Pareto efficient. ${ }^{17}$

The fact that competition leads to an efficient allocation of resources does not necessarily mean that the government should refrain from intervening in the economy. ${ }^{18}$ Most economists recognize at least two legitimate governmental functions. First, the government performs a distributive function. For example, the government collects taxes and redistributes income through social security, medicare, and other social welfare programs. Economics also posits an allocative function for the government. Acting in this capacity, the government creates and maintains conditions under which a competitive equilibrium will likely arise. For example, the government often takes steps to correct market failures. ${ }^{19}$ The mere existence of a market failure, however, does not necessarily mean that governmental action will achieve a superior result. Governmental regulation involves great administrative costs, as well as the costs of gathering the large amounts of information necessary for effective regulation. There is no guarantee that the benefits achieved by the correction of a market failure will outweigh these costs.

13 See R. Russell \& M. Wilkinson, supra note 5, at 217-19 (summarizing all assumptions needed for competitive equilibrium). Transaction costs include, among other things, the costs of obtaining information relevant to rational buying and selling, the costs of finding trading partners, and the costs of drafting and enforcing contracts.

14 Externalities describe certain situations in which an individual's utility or a firm's profits are affected by activities of other individuals or firms that do not involve market transactions. For example, polluting a river involves no market transaction and results in an externality to a person living downstream from the polluter. See id. at 373-74. Other examples of externalities include a rancher's cattle straying onto a farmer's land and damaging the crops, and the noise from a confectioner's machine penetrating the walls of a neighboring doctor's office. See Coase, The Problem of Social Cost, 3 J.L. \& Econ. 1, 2 (1960).

15 See R. Russell \& M. Wilkinson, supra note 5, at 375-79.

${ }^{16}$ An excess of supply over demand in a given market will cause a decline in price, whereas an excess of demand over supply in a given market will cause an increase in price. Eventually, prices in all markets will be such that supply equals demand, and the market will reach a state of competitive equilibrium.

${ }^{17}$ The proposition that competitive-equilibrium allocations are always efficient is known as the first fundamental theorem of welfare economics. See R. TRESCH, PUBLIC Finance: A Normative Theory 7-8 (1981). For a mathematical demonstration of the argument, see R. Russell \& M. WILKINSON, supra note 5, at 363-64.

18 See P. SAMUEISON, supra note 4, at 398-99.

19 See id. 


\section{B. The Coase Theorem of Social Cost ${ }^{20}$}

The idea that market failures do not necessarily warrant governmental intervention provided the impetus for a paper by Professor Ronald Coase ${ }^{21}$ that Judge Posner credits with helping to start the "law and economics" movement. ${ }^{22}$ Market failures are often caused by externalities-the incidental effects on third parties that sometimes result from economic interactions. ${ }^{28}$ Yet Goase argued that governmental restriction or prohibition of externality-producing activities is not always desirable. Coase asserted that society should weigh the harm caused by the externalities against the harm caused by restricting the underlying economic activity, and avoid the more serious harm. ${ }^{24}$

Coase's primary insight was to notice that, through bargaining under competitive conditions, individuals will achieve this result on their own. Coase developed two propositions, which will be valid as long as high transaction costs do not impede bargaining. First, even in the presence of externalities, the allocation of resources will be efficient-that is, society will undertake only the activities that generate more benefits than harms. ${ }^{25}$ Second, the same efficient allocation will result regardless of which party has the legal right to conduct the activity or to avoid its effects. ${ }^{26}$ Therefore, private bargaining, if not too costly, can overcome the problem of externalities by fostering only those activities that provide more social benefit than social cost.

Coase illustrated these results by examining the case of a confectioner installing a loud machine next door to a doctor who requires quiet. ${ }^{27}$ If the doctor has the legal right to be compensated for damages, and if the benefit from the machine is less than the harm caused to the doctor, then the confectioner will decide to stop using the machine. If, however, the benefit exceeds the harm, then the confectioner should strike a bargain with the doctor: she should promise to pay the doctor some amount greater than the harm and less than the benefit, on the condition that the doctor will allow the machine to run. Both the doctor and the confectioner will be better off as a result of the bargain. On the other hand, if the confectioner has the right to operate the machine

${ }^{20}$ Although Goase did not formalize his assumptions and conclusions into precise mathematical form, subsequent scholars have called his argument a "theorem."

S1 See Coase, supra note 14.

22 See R. Posner, Economic Analysis of Law 16 (2d ed. 1977).

${ }^{23}$ For a description of externalities, see supra note 14.

24 See Coase, supra note 14, at 2.

25 See id. at 2-6.

36 See id. at 2-8.

27 See id. at 8-10. Coase's illustration is from Sturges v. Bridgeman, $11 \mathrm{Ch}$. D. 852 (1879). 
regardless of the harm it causes, and if the harm exceeds the benefit, then the doctor will pay the confectioner some amount greater than the benefit and less than the harm not to use the machine. ${ }^{28}$ If the benefit exceeds the harm, the confectioner will demand more from the doctor than the doctor is willing to pay, and the machine will continue to run. Thus, regardless of the assignment of rights and without the intervention of government, the confectioner will operate the machine only if the benefit outweighs the harm to the doctor. ${ }^{29}$

\section{The Cost-Benefit Approach to Problem Solving}

Coase's two propositions derive from his original premise that society should promote activities having benefits that outweigh their costs. This cost-benefit approach to decisionmaking pervades applied econom-

${ }^{28}$ Some readers may benefit from a mathematical treatment of Coase's proposition. Let $P_{d}$ and $P_{c}$ be the profits for the doctor and confectioner, respectively. Let $R_{d}$ and $R_{c}$ be their revenues before the machine is installed. Let $C_{d}$ and $C_{c}$ be their costs. Finally, let $H$ be the harm to the doctor from the machine, $B$ the benefit to the confectioner, and $X$ the transfer payment (either court ordered or privately bargained).

Case 1: The doctor has the right to a quiet office. If the confectioner is not allowed to run the machine, the parties' respective profits would be

$$
\begin{aligned}
& P_{d}=R_{d}-C_{d} \\
& P_{c}=R_{c}-C_{c}
\end{aligned}
$$

If $B>H$, then the confectioner should pay the doctor some $X$, with $B>X>H$, so that the doctor will allow the machine to run. Profits would then be

$$
\begin{aligned}
& P_{d}=R_{d}+(-H+X)-C_{d} \\
& P_{c}=R_{c}+(B-X)-C_{c}
\end{aligned}
$$

As a result, both $P_{d}$ and $P_{c}$ increase. In contrast, if $B<H$, then the confectioner will not use the machine because, no matter what she does, $P_{c}$ will decrease.

Case 2: The confectioner has the right to use the machine. When the confectioner uses the machine, the parties' respective profits are

$$
\begin{aligned}
& P_{d}=R_{d}-H-C_{d} \\
& P_{c}=R_{c}+B-C_{c}
\end{aligned}
$$

If $B>H$, then the doctor will let the machine run and suffer the harm, because she cannot increase her profits through bargaining. If $B<H$, then the doctor will pay the confectioner some $X$, with $H>X>B$, so that the confectioner will not use the machine. As a result, the parties' respective profits would be

$$
\begin{aligned}
& P_{d}=R_{d}-X-C_{d} \\
& P_{c}=R_{c}+X-C_{c}
\end{aligned}
$$

and $P_{d}$ and $P_{c}$ will increase.

Thus, the only relevant factor in determining whether or not the confectioner will use the machine is whether $B$ is greater or less than $H$.

20 There is still an important difference between giving the right to the doctor or the confectioner. If the doctor has the right to quiet, she will be better off in the end than if the confectioner has the right to use the machine, and likewise for the confectioner. See Coase, supra note 14, at 9-10. That is, the delimitation of rights affects the distribution of income between the doctor and the confectioner, even though the allocation of resources remains the same. 
ics and often informs conventional legal analysis. ${ }^{30}$

The economic theory behind cost-benefit analysis stems from the concept of Pareto efficiency. Faced with the choice of whether or not to undertake a given activity, a lawmaker would first want to consider whether the activity results in a Pareto improvement-that is, whether the activity makes at least some people better off, and no one worse off, than they are at present. Such Pareto improvements bring society one step closer to efficiency. ${ }^{31}$ Judges and most other government officials, however, rarely have the opportunity to make Pareto-improving decisions; their decisions inevitably help some and hurt others. Lawmakers must therefore resort to another criterion for decisionmaking. The alternative supplied by economics is the "compensation criterion": society should undertake an activity if those who benefit from it can potentially compensate those who are harmed by it. ${ }^{32}$ Thus, if the benefits of an activity outweigh the costs, society should engage in that activity because everyone can be made better off by redistributing the benefits to the losers until they are fully compensated.

There are several problems with using the compensation criterion, however. First, actual compensation may never be awarded; in most cases, there will in fact be winners and losers. Economists would argue that this is merely a problem of redistribution that can be corrected through appropriate taxation and transfer policies. ${ }^{33}$ But redistributive

so Judge Posner is not the first to apply cost-benefit reasoning from the bench; the methodology is particularly ubiquitous in the area of torts. See W. KEETON, D. DoBBS, R. Keeton \& D. OWen, Prosser and Keeton on the Law of Torts 169-73 (5th ed. 1984); see also infra notes 105-11 and accompanying text (discussing the costbenefit analysis of negligence formulated in United States v. Carroll Towing Co., 159 F.2d 169 (2d Cir. 1947)). Posner, however, appears to be one of the first judges to apply cost-benefit reasoning systematically to a wide variety of situations. See, e.g., infra text accompanying notes 112-22 (discussing cases in which Posner uses cost-benefit analysis in defining constitutional rights and in determining whether certain employee conduct is protected under the National Labor Relations Act).

s1 Technically, economists would not say that society is made "more efficient" by these improvements, because the idea of a "more efficient" allocation of resources makes no more sense than the idea of a "more perfect" being. Because of such semantic problems, economists prefer the more precise term "Pareto optimality." This Comment employs the term "efficiency" in order to reflect Judge Posner's terminology.

${ }^{32}$ See H. VARIAN, Microeconomic ANALYSIS 216 (1978); see also R. TResch, supra note 17, at 547-48 (noting that the compensation criterion is also known as the Hicks-Kaldor criterion).

ss See H. VARIAN, supra note 32 , at 216 . The basis for this argument is the socalled second fundamental theorem of welfare economics, which states that any desired efficient allocation of resources can be achieved through a system of competitive prices coupled with redistribution through appropriate lump sum taxes and transfers. The government could tax the winners and make transfer payments to the losers so as to achieve an allocation that improves everyone's position. See P. Samuelson, supra note 4 , at $163-65$. 
questions are not easily solved, and lawmakers should therefore be wary in their use of cost-benefit analysis. ${ }^{34}$ Second, if activities have equal costs and benefits, the compensation criterion gives no guidance regarding the determination of the better choice. ${ }^{38}$ Finally, the compensation principle does not rule out the possibility that society would prefer to maintain the status quo even when the benefits of a proposed new activity would outweigh the costs. ${ }^{36}$

Cost-benefit analysis also poses a number of practical problems. If the costs and benefits of an activity are known, but uncertain to occur, they can be discounted by the probability of their occurrence. ${ }^{32}$ Identifying and measuring the particular costs and benefits of an activity, however, may be difficult. So long as markets are competitive, the costs and benefits of private goods are reflected in their prices, but the costs and benefits of many other goods and activities do not easily lend themselves to measurement. For example, it is difficult to place a value on a human life or the exercise of a constitutional right. ${ }^{38}$

\section{Posner's Economic Analysis of Law}

Judge Posner's academic work utilizes the foregoing analytic tools to fashion economic approaches to legal problems. Posner has suggested that economics may be used to determine the "extent [to which] the common law is a coherent system of rules concerned with promoting

s4 If the prospective losers in an otherwise beneficial legislative scheme are already disadvantaged members of society, a lawmaker concerned with equity might want some guarantee that the losers would in fact be compensated in some way. Consider, for example, a proposal to build a highway on urban property that is currently occupied by slum housing. The highway would improve the city's infrastructure and would employ a great number of the city's residents. Yet the project would displace the already impoverished residents of the housing in the highway's path. Under the compensation criterion, the problem might be rectified by paying moving costs and making new housing available for comparable rent, but the probability that the city would actually provide such compensation is not high. Even if it did, the displaced residents would still bear the loss of their neighborhood and community. Cf. R. Caro, The Power BroKER: ROBERT MOSES AND THE FALL OF NEW YORK 850-94 (1975) (describing dislocations caused by construction of the Cross-Bronx Expressway).

ss See H. VARIAN, supra note 32 , at 217 . In the case of the confectioner and the doctor, see supra notes $27-29$ and accompanying text, if the social costs and benefits of running or not running the machine are equal, then the compensation criterion alone cannot determine the outcome. The total benefits will be the same regardless of which activity is chosen. Thus, the choice must be made with reference to a normative decision regarding who has the greater right to engage in the chosen activity. See supra note 29.

so See H. VARIAN, supra note 32 , at 217.

s7 The most common use of this technique in law is Learned Hand's "BPL" formula. See infra text accompanying notes 105-07.

s8 Posner's relatively frequent use of cost-benefit analysis suggests that these difficulties do not bother him. In fairness to Posner, it should be noted that the legal system constantly requires the valuation of intangibles in order to calculate money damages. 
efficiency."39 In fact, efficiency concerns so dominate Posner's approach to jurisprudence that he has even suggested that "efficiency" may be the equivalent of "justice" in many cases. ${ }^{40} \mathrm{It}$ is important, therefore, to clarify what Posner means by "efficiency." Posner does not use efficiency in its narrow sense, to mean Pareto optimality, but in a broader sense, to refer to a situation in which aggregate net benefits (the "size of the pie," to use the economists' metaphor) are as large as possible."1 This conception of efficiency, which Posner has termed "wealth maximization,"42 simply incorporates the compensation criterion. ${ }^{43}$ If total wealth would increase under a given policy, one can infer that the benefits of that policy outweigh the costs. ${ }^{44}$

Using wealth maximization, or Posnerian efficiency, as his focal point, Posner has derived specific theories of discrete aspects of the legal system. These theories represent both a positive and a normative application of economic analysis to judicial decisionmaking-that is, they both describe what judges do and suggest what judges ought to do when deciding cases. ${ }^{45}$ This section will sketch two such theories that have influenced Posner's judicial work: ${ }^{46}$ the economic theory of procedure and the economic theory of statutory and constitutional interpreta-

39 Posner, The Present Situation in Legal Scholarship, 90 YALE L.J. 1113, 1120 (1981).

10 Posner contends that use of the term "unjust" in the legal context can usually be interpreted to mean that the activity is inefficient-that is, a waste of resources. He illustrates his argument with the following examples: convicting persons without trial, taking property without compensation, and failing to require a negligent driver to compensate a victim. Posner recognizes, however, that many propositions frequently described as "unjust" are not necessarily economically inefficient. Enforcing suicide pacts, allowing prisoners to engage in medical experiments, and allowing babies to be sold for adoption are some examples. Posner argues that economic analysis should be used to determine the cost of attaining ideals of justice not related to efficiency. Society could then decide if these noneconomic ideals of justice are worth the cost. See R. Posner, supra note 22 , at $22-23$.

4 In his textbook, Economic Analysis of Law, Posner describes efficiency as "exploiting economic resources in such a way that 'value'-human satisfaction as measured by aggregate consumer willingness to pay for goods and services-is maximized." R. Posner, supra note 22, at 10.

12 Posner, Utilitarianism, Economics, and Legal Theory, 8 J. LEGAL STUD. 103, 127 (1979) (delineating Posner's version of the wealth maximization principle). Posner often uses the terms "efficiency" and "wealth maximization" interchangeably. See, e.g., Posner, Some Uses and Abuses of Economics in Law, 46 U. CHI. L. REV. 281, 291 (1979) (explicitly noting his use of "efficiency" in the sense of wealth maximization).

43 See Samuels \& Mercuro, supra note 1, at 108.

$4 C f$. H. VARIAN, supra note 32 , at 218 (reaching this conclusion in connection with the compensation criterion).

45 See Samuels \& Mercuro, supra note 1, at 107.

46 Posner has not explicitly advocated wealth maximization in any of his judicial opinions. See id. at 110. This goal is implicit, however, in his extensive use of costbenefit analysis and in his definition of efficiency. See infra text accompanying notes 105-22. 
tion. Although Posner's economic theories of the common law are perhaps better known, these two theories involve areas of law more frequently encountered in the federal courts.

\section{The Economic Theory of Procedure}

Posner's procedural theories may be understood in terms of an economic view of government as a large firm engaged in the production of laws that move society toward an efficient allocation of resources. Economists postulate cost-minimization as a goal for firms; ${ }^{47}$ presumably, a government acting as a firm would also seek to minimize costs. ${ }^{48}$

Posner's economic theory of legal procedure ${ }^{49}$ conforms with this view of government. He argues that legal procedure aims to minimize the sum of two costs: "error costs"-the social costs resulting from the judicial system's mistakes in adjudicating cases-and "direct costs" - the actual costs involved in litigation activity. In Posner's view, the procedural mechanisms of the legal system promote efficiency through their tendency to minimize both of these costs. ${ }^{50}$

Although rules of procedure often promote efficiency, they sometimes produce the opposite result. For example, discovery rules often reduce direct costs by making settlement more likely ${ }^{61}$ and reduce error costs by enabling parties to obtain information relevant to their disputes. $^{\mathbf{6 2}}$ Abuses of discovery, however, may increase both direct and error costs. ${ }^{53}$ Similarly, the doctrine of res judicata arguably saves direct costs by barring suits that would otherwise be litigated. ${ }^{54}$ The doctrine also seems unlikely to impose frequent error costs, because in most cases courts' decisions will not improve on successive efforts. ${ }^{65}$ Never-

17 For firms that must produce a set quantity of goods, cost minimization functions as the equivalent of profit maximization. Cf. P. SAMUELSon, supra note 4, at 495 (explaining the general relationship between a firm's total profits and its total costs).

18 This view of government is implicit in Posner's analysis of procedural rules as cost-avoidance mechanisms. See R. POSNER, supra note 22, at 429-58; $c f$. id. at 419-27 (analyzing legal rules as capital goods).

19 See Posner, An Economic Approach to Legal Procedure and Judicial Administration, 2 J. Legal STUd. 399 (1973).

${ }^{s 0}$ See id. at 400 . But $o f$. id. at 435 (acknowledging that procedural rules designed to promote efficiency may not always result in the reduction of litigation costs).

${ }^{51}$ See id. at $422-26$.

s2 See id. at 436-37.

ss See infra text accompanying notes $129-45$ (discussing a case in which Posner makes this argument).

* See Posner, supra note 49, at 444-45. Posner argues that res judicata rules in fact save little in direct costs because, even in the absence of formal rules, many losing plaintiffs will view the expected value of subsequent legal action as too low to warrant the costs of further litigation.

os See id. at 445. 
theless, there may be cases in which the initial outcome is actually incorrect. In those cases, the application of res judicata may impose large error costs on the litigants.

These potential deviations from efficiency suggest that Posner's theory bears upon the normative question of how cases should be decided. Legal rules, in and of themselves, cannot guarantee efficiency. Thus, the implication is that judges should apply procedural rules in a manner that furthers the goal of cost-minimization. ${ }^{\text {s6 }}$

\section{The Economic Theory of Statutory and Constitutional Interpretation}

Another area of law to which Posner has recently applied economic analysis is the interpretation of statutes and the Constitution. ${ }^{\mathbf{5 7}}$ These theories merit special attention because they are distinctly Posnerian, in contrast to some of Posner's more widely accepted applications of law and economics. In addition, they go far beyond traditional Coasian cost-benefit analysis to a frontier that many believe economic analysis cannot conquer.

Posner's approach to statutory interpretation begins with an inquiry into the causes of legislation. Economists have propounded several theories describing the incentives that motivate the enactment of legislation..$^{58}$ Posner's approach is an amalgam of two of these theories: the public interest theory and the interest group theory. ${ }^{59}$

According to the public interest theory, the legislative process is directed toward the identification of market failures that are potentially amenable to statutory correction. ${ }^{60}$ In this scenario, civic duty and electoral pressure motivate legislators to draft laws that either increase economic welfare by promoting efficiency or enhance equity by redistrib-

56 How this should be done is not at all clear. In the application of discovery rules, a judge must identify and promote an optimal level of discovery. This would probably vary with each case; at any rate, even the identification of a uniform level is likely to be an elusive task. Given that Posner's theory embraces the reduction of error costs, he would presumably hesitate to apply res judicata rules in cases in which they would generate such costs. Identifying those cases may be quite difficult, however. $C f$. infra notes 248-52 and accompanying text (usefulness of economic analysis is limited by information problems).

${ }^{57}$ See Posner, Economics, Politics, and the Reading of Statutes and the Constitution, 49 U. CHI. L. Rev. 263 (1982).

${ }^{58}$ See id. at 265-69 (describing three major economic theories of legislation).

69 See id. at 269-72. Posner does not believe that his theory of the legislative process differs from the traditional legal theory that "legislation is designed to protect the public interest, implicitly defined in utilitarian terms." Id. at 265.

so See id. at 269. 
uting wealth. ${ }^{61}$ The resulting laws are termed public interest legislation.

On the other hand, the interest group theory of legislation is premised on the view that laws are "good[s] demanded and supplied much as other goods." ${ }^{12}$ In the marketplace for legislative goods, interest groups offer legislators various incentives, both legal and illegal, to induce the enactment of laws that redistribute wealth to these groups. ${ }^{63}$ The resulting laws are termed interest group legislation.

Posner contrasts the two forms of legislation by noting that the redistributions effected by interest groups "have nothing to do with the public interest, whether defined in efficiency or equity terms. . . . [T] hey tend to make legislation systematically perverse from a public interest standpoint by fostering the redistribution of wealth from large groups . . . to small ones." ${ }^{14}$ Thus, public interest legislation fosters efficiency and equity, whereas interest group legislation is "amorally redistributive."

Posner suggests that the interpretation of legislative intent should reflect the particular type of legislation at hand. ${ }^{\mathbf{6}}$ Specifically, Posner advocates interpreting public interest legislation in the manner that will best achieve the public interest, and interest group legislation in the manner that will best achieve the limited benefit that the legislators intended to confer. ${ }^{67}$ In making these distinctions, courts would promote efficiency and avoid the error costs incurred in thwarting the will of the majority. ${ }^{68}$

Posner describes the interest group method, which strongly resembles traditional contract interpretation, as "imaginative reconstruction" of the legislative bargain. ${ }^{69}$ This reconstruction involves examining the act's language and history and inquiring into "the values and attitudes ... of the period" of its enactment, with particular attention to any legislative views on the scope of subsequent judicial

e1 See id. at 265.

${ }^{62} I d$.

ss See id. at 265-68.

B4 Id. at 266 .

es Id. at 268.

${ }^{\text {B }}$ See Posner, Statutory Interpretation-in the Classroom and in the Courtroom, 50 U. CHI. L. REv. 800, 809 (1983) (broad construction of interest group legislation upsets the compromise the statute was intended to embody); see also R. POSNER, supra note 22, at 409; Posner, supra note 57, at 276-80.

67 See R. PosNER, supra note 22, at 409.

${ }^{68}$ See Posner, supra note 57, at 284.

${ }^{69}$ See Posner, supra note 66 , at 817 . "The judge should try to think his way as best he can into the minds of the enacting legislators and imagine how they would have wanted the statute applied to the case at bar." Id. 
interpretation. $^{\mathbf{7 0}}$

Although Posner acknowledges that judges will often encounter great difficulty in distinguishing the two types of legislation, ${ }^{71}$ he implies that most statutes reflect significant influence from interest groups. Thus, application of interest group interpretation appears to be warranted in ambiguous cases. ${ }^{\mathbf{7 2}}$ Posner also suggests that statutes having no discoverable legislative intent may legitimately be interpreted by reference to considerations other than the will of the drafters. ${ }^{73}$

The Constitution does not lend itself so easily to an "intent of the drafters" methodology. ${ }^{74}$ As Posner himself notes, reconstructing the intent of constitutional provisions requires historical research that is generally beyond the scope of judicial competence. Furthermore, even if judges could undertake such research, the uncertainty of the inquiry would yield unreliable results. ${ }^{75}$ These difficulties of constitutional interpretation lead Posner to conclude that errors are more likely to occur in constitutional than in statutory interpretation. ${ }^{76}$

Posner thus argues that the "utilitarian notions that underlie most versions of welfare economics, coupled with considerations of political prudence frankly imported from outside economics, indicate that, in general, constitutional rights should be narrowly construed but constitutional powers broadly construed."77 This distinction between individual constitutional rights and institutional constitutional powers ostensi-

70 See id. at 818. The interpretation of public interest legislation implicates a similar analysis; however, reconstruction in that context involves the relatively straightforward task of identifying the public interest embraced by the statute. The primary difference between the two methods seems to be in the breadth of interpretation that is permitted.

71 [I] the output of a legislature is a mixture of public interest and interest group statutes . . that are difficult to classify into either group, and if, moreover, courts lack the research tools they need to classify statutes correctly, what is the judge to do ... ? As a matter of logic, it seems he cannot act at all without determining whether a statute is motivated by public interest or interest group considerations-a determination beyond his competence.

Posner, supra note 57, at 279.

${ }_{72}$ See id. at 274-75. Posner has argued, however, that courts should not presume the influence of interest group pressure, for "[m]any statutes really are enacted in the public interest." Id. at 272-73.

${ }^{73}$ See Posner, supra note 66 , at 820 . Some of the alternative guides to statutory interpretation include considerations of judicial administrability, conceptions of the public interest, or presumed legislative intent. See id.

74 Posner does argue, however, that a constitutional provision with an unambiguous historical meaning should be interpreted in accordance with that meaning unless a contrary meaning is conveyed by well-established precedent. See Posner, supra note 57, at 283.

${ }^{75}$ See id.

${ }^{76}$ See id. at 284.

$77 \mathrm{Id}$. at 285. 
bly rests upon an efficiency argument. Starting with the assumption that the incidence of error in constitutional interpretation is relatively high, Posner assesses the social costs of such errors. He concludes that total social utility will decline more if the will of the majority is thwarted by the invalidation of unconstitutional statutes than if the interests of an individual are thwarted by the denial of constitutional rights. ${ }^{78}$ Thus, under this utilitarian approach the scope of construction for individual rights will be narrower than the scope of construction for governmental powers. Posner further argues that his analysis holds true even when governmental powers are exercised in the furtherance of interest group, rather than public interest, legislation. In such cases, "political prudence" dictates that courts still should favor the powers of legislatures over individual rights because statutes reflect the dominant power in society. ${ }^{78}$

The elements of Judge Posner's economic analysis examined above do not exhaust the scope of his theoretical work; ${ }^{\mathbf{8 0}}$ nevertheless, these elements do suggest the basic tenor of Posner's methodology and appear more frequently in Posner's opinions. The theoretical tools of the competitive market, the Coase Theorem, cost-benefit analysis, and Posner's theories of procedure and interpretation represent potentially powerful aids to judicial decisionmaking. Like all theoretical tools, however, the tools of economics must be used carefully and with an appreciation of their limitations. The next section will assess Judge Posner's use of these tools by examining his judicial handiwork.

\section{Posnerian Analysis in Practice}

Posner has used economic analysis explicitly in only a small fraction of the opinions he has issued from the bench. ${ }^{81}$ Moreover, he

78 See id. at 284. Elsewhere, Posner argues that nonpolitical constitutional rights should be construed narrowly because they are best viewed as "a particularly durable form of legislative protection obtained by particularly effective interest groups." $R$. Posner, supra note 22, at 494.

70 See Posner, supra note 57, at 284-85. Posner does not offer any economic analysis to justify this assertion, most likely because neoclassical economics currently has little to say about political power. To the extent that Posner's economic theories of law implicate political theories of power, Posner appears to have a strongly majoritarian perspective. In particular, his theory of constitutional interpretation ignores alternative, noneconomic theories supporting a broader reading of constitutional rights, such as the concern in traditional democratic theory with protecting minorities from the tyranny of the majority.

80 For a sampling of the broad range of topics to which Posner has applied his theories, see R. POSNER, supra note 22.

81 One article cites Posner as claiming to have used economic analysis in at least 20 decisions out of the more than 200 that he has authored. See Caplan, supra note 2, at D4, col. 1. But of. Samuels \& Mercuro, supra note 1, at 124 n.10 (reporting that 98 
rarely highlights the economic analysis that does appear in his opinions; instead, he subtly weaves it into the rationale of the opinion as though it represented no radical departure from conventional legal analysis.

These observations might not surprise someone familiar with Posner's contention that economic analysis is better used to describe the effects of the law than to determine the law itself. In Posner's words, "Few legal opinions . . . contain explicit references to economic concepts, and few judges have a substantial background in economics. But the true grounds of legal decision are often concealed rather than illuminated by the characteristic rhetoric of judicial opinions . . . ."82

Whatever the case may be with other judges, Posner does have a substantial economics background and has made explicit references to economic concepts in his opinions. Thus, although Posner has used economic analysis to make normative decisions on how the law should look, his judicial rhetoric often sheds little more light on the "true grounds" of his decisions than the rhetoric of other judges. This section aims to examine some of Posner's innovative and controversial decisions.

\section{A. Competitive Market}

Discussions of how well the competitive market works in a given industry abound in antitrust and regulation cases. ${ }^{83}$ Posner's contribution to jurisprudence has been to apply traditional price theory to other areas of the law. The market for legal services provides the best example of such an area in Posner's judicial work to date. In Merritt $v$. Faulkner, ${ }^{84}$ a prison doctor allegedly misdiagnosed and mistreated an indigent prisoner. As a result, the prisoner lost sight in one eye. The prisoner filed suit, charging a violation of his rights under the eighth amendment. The trial judge denied the prisoner's motion for appointment of counsel, and the prisoner appealed.

Over Posner's dissent, the court of appeals held that the trial judge had abused his discretion by denying counsel to the prisoner. ${ }^{85}$ Posner responded that "a prisoner who has a good damages suit should be able to hire a competent lawyer and . . . by making the prisoner go this

out of Posner's first 120 decisions were of "direct use" in their study).

${ }_{82} R$. Posner, supra note 22, at 18.

ss See, e.g., United States v. E.I. du Pont de Nemours \& Co., 351 U.S. 377 (1956) (packaging materials industry); Appalachian Coals, Inc. v. United States, 288 U.S. 344 (1933) (fuel industry).

84 697. F.2d 761 (7th Cir. 1983), cert. denied, 104 S. Ct. 434 (1984).

${ }^{85}$ See id. at 764-65. 
route we subject the probable merit of his case to the test of the market." ${ }^{\text {"88 }}$ This market test derives from the fact that, unlike criminal defendants, plaintiffs in civil cases often can retain lawyers in the private market through a contingency-fee arrangement. According to Posner, if the plaintiff cannot secure a lawyer, the market has rejected his claim as unworthy of representation, and so should the court. ${ }^{87}$

Posner also rejected the majority's claim that prisoners have difficulty getting the names of potential lawyers and are therefore entitled to have the court step in where the market has failed. Posner maintained that if this type of market failure were present the proper corrective action would be to supply prisoners with lists of lawyers willing to represent prisoners on a contingency basis. ${ }^{88}$

Merritt involved a direct analysis of the market for legal services. In Sutter v. Groen, ${ }^{88}$ Posner used market analysis indirectly in formulating a rule of corporate law. The court in Sutter held that an SEC regulation forbidding misrepresentation in the sale of any security protects only persons who purchase securities for investment and not those who purchase for entrepreneurial control..$^{80}$ In examining the advantages and disadvantages of adopting a legal distinction between "investors" and "entrepreneurs," Posner considered whether the increased costs of future judicial distinctions between these two categories should be avoided by protecting entrepreneurs as well as investors. In rejecting this reasoning, he argued that

the costs of administering legal rules are a proper concern in designing those rules. But rarely will a net saving in those costs be produced by expanding liability, since even if the legal standard will be simpler and therefore cheaper to apply in each case the number of potential cases in which it will be applied will be greater. ${ }^{91}$

Posner's argument envisions a market for civil litigation supplied by the legal system and demanded by litigants. His conclusion that the expansion of liability will rarely increase net savings requires the assumption, which Posner neither states nor justifies, that the demand for

${ }^{86}$ Id. at 769 (Posner, J., dissenting in part). Posner made almost the identical argument in an earlier case involving an indigent prisoner's right to counsel in a civil action. See McKeever v. Israel, 689 F.2d 1315, 1324-25 (7th Cir. 1982) (Posner, J., dissenting).

${ }^{87}$ See Merritt, 697 F.2d at 770 ("If Merritt cannot retain a lawyer on a contingent fee basis the natural inference to draw is that he does not have a good case.").

88 See id.

89687 F.2d 197 (7th Gir. 1982).

so See id. at 202 .

91 Id. 
such litigation is relatively elastic. ${ }^{\mathbf{2}}$

\section{B. Coase Theorem}

The theory that competitive trading between buyers and sellers reveals the true value of goods parallels Coase's assertion that bargaining between buyers and sellers reveals the true social cost of externalities when no transaction costs are present. ${ }^{93}$ Posner has made explicit use of the Coase Theorem in a number of cases. In United States Fidelity $\mathcal{E}$ Guaranty Co. v. Jadranska Slobodna Plovidba, ${ }^{94}$ the court, through Posner, upheld a jury's finding that a shipowner was not liable for the death of a longshoreman who had fallen through an open hatch in a dark hold of a ship. Posner invoked Coase to support his argument

92 For a discussion of elasticity, see P. SAmuelson, supra note 4, at 381-87. The argument can be made clèrer by means of a simple diagram. Let $D$ be the market demand curve for litigation, measured in cases per year. The demand for litigation depends on the opportunity cost (price) per case, which in turn depends on such factors as the duration of litigation and the likelihood of victory. In Figure $1, D$ is relatively elastic; that is, a small change in the market price of litigation induces a large change in the number of cases demanded. In Figure 2, $D$ is relatively inelastic; that is, a small change in the market price of litigation induces only a small change in the number of cases demanded. Let $S$ be the amount of litigation supplied by the legal system (lawyers as well as courts) before the cost-saving rule, and $S^{\prime}$ be the amount of litigation supplied after the cost-saving rule. The supply curve is drawn inelastically, since supply of litigation ordinarily does not depend greatly on market price. Note that the supply curve shifts outward in this case for two reasons: the rule reduces administrative costs and increases the likelihood of victory. The total costs of litigation are indicated by the rectangle created by the intersection of supply and demand. The slashed rectangle indicates the total costs before the adoption cost-saving rule, and the dotted rectangle indicates the total costs after the adoption of the cost-saving rule. In Figure 1, costs increase, but in Figure 2, costs decrease as a result of the expansion of liability.

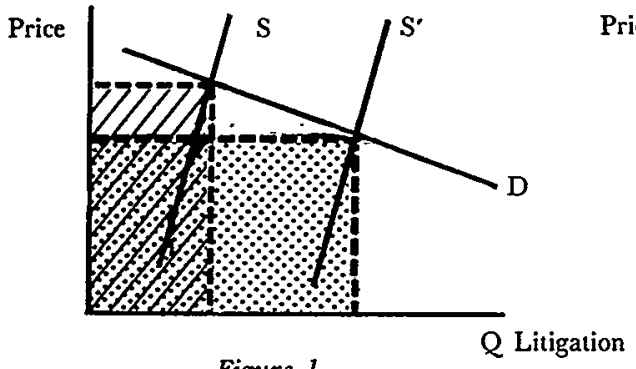

Figure 1

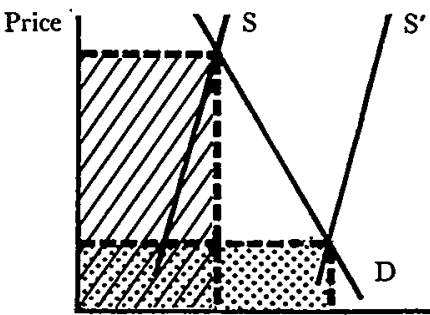

Figure 2
Q Litigation

Thus, it is not necessarily true that a net savings in costs from simplifying legal rules will be rare. If demand is inelastic, total costs could go down. The elasticity of demand for litigation becomes important in other cases in which judges worry about "opening the floodgates" by expanding liability. With an inelastic demand, the gates would open only a notch.

93 See supra notes $20-29$ and accompanying text.

94683 F.2d 1022 (7th Cir. 1982). 
that the trade custom of leaving hatches open in darkened holds was evidence that the dangerous practice was cost-justified and hence not negligent.95

Focusing on the relationship between the shipowner and the stevedore, ${ }^{96}$ Posner first noted that the stevedore had a statutory obligation to compensate the longshoreman for injury and thus bore the external social cost of the shipowner's dangerous activity. ${ }^{87}$ If the labor market for the stevedore's services were competitive, the shipowner would have to pay a wage premium reflecting compensation for expected accident costs. ${ }^{98}$ Furthermore, if the expected accident costs exceeded the costs of preventive measures, the shipowner would prefer to pay for the preventive measures rather than to pay the wage premium to the stevedore. ${ }^{99}$ Posner observed that in this case preventive measures were not undertaken, and he therefore inferred that the benefits of the activity outweighed the costs. Under these circumstances, the shipowner's activity was considered socially cost-justified and not negligent. ${ }^{100}$

A second case in which Posner explicitly applied the Coase Theorem, Powers v. United States Postal Service, ${ }^{101}$ extended Coase's ideas to the area of property law. In Powers, the court held that state law, rather than federal common law, applied to a landlord-tenant dispute involving the Postal Service as a tenant. Under state law, the landlord could bring an ejectment action. One argument advanced in favor of applying federal common law, which might have barred the ejectment, was that by applying state law and allowing the ejectment the Postal Service would lose the benefits of its long-term, low-rent lease, ${ }^{102}$ and costs to the government would rise substantially. Posner countered by asserting that the

advantage [of applying federal common law] would be transitory. Knowing that they would have fewer rights under federal leases than state law (if applicable) would have given them, . . . landlords would in the future drive harder bargains with the Postal Service. Concretely, the more difficult a lease is to terminate, the higher will be the rent to the landlord; there will be no net saving to the tenant in the long

95 See id. at 1028-29.

The stevedore was the longshoreman's employer. See id. at 1024.

97 The statute provided that regardless of fault the stevedore must compensate a longshoreman injured in the course of employment. See id. at 1029.

ss See id.

2 See id. (citing Coase, supra note 14).

100 See id.

101671 F.2d 1041 (7th Cir. 1982).

102 See id. at 1044. 
run. ${ }^{103}$

On the other hand, if state law were applied, the future rent paid by the Postal Service would be lower, because landlords would compensate the Postal Service for the stricter legal rules. The implication that Coase would draw from Posner's analysis is that the quantity of rental services demanded by the Postal Service would in the long run be unaffected by the choice of law. ${ }^{104}$

\section{Cost-Benefit Analysis}

While Posner's application of the Coase Theorem to legal decisions breaks new jurisprudential ground, cost-benefit analysis in some form has influenced judges' opinions for some time, especially in tort cases. Judge Posner's major contribution has been to extend this analysis to a wider variety of subjects and to accord it greater and more explicit weight than other jurists. In addition, Posner has strengthened the traditional uses of cost-benefit analysis in legal reasoning.

For example, in United States Fidelity, discussed in the previous section, Posner adopted the commonly accepted Learned Hand formula ${ }^{105}$ as the proper standard of negligence in tort actions brought under the Longshoremen's and Harbor Workers' Compensation Act. ${ }^{106}$ The Learned Hand formula compares the burden of accident prevention, $B$ (alternatively, the benefit of the dangerous activity), with the expected accident costs, $P L$ (the magnitude of the harm caused by an accident, $L$, discounted by the probability that the accident will occur, $P$ ). If $B<P L$, the person engaging in the dangerous activity will be judged negligent. Endorsing the traditional Hand formula, Posner asserted that it "does not yield mathematically precise results in practice . . . . Nevertheless, the formula is a valuable aid to clear thinking about the factors that are relevant to a judgment of negligence and about the relationship among those factors.":

Posner applied Hand's formula to support the jury's finding that the shipowner was not negligent. The magnitude of loss, $L$, was large, because a fall into the ship's hold was very likely to cause serious in-

${ }^{103} I d$. at 1044 (citing Coase, supra note 14).

104 This result is simply Coase's neutrality proposition. See supra text accompanying note 26.

${ }_{105}$ See United States v. Carroll Towing Co., 159 F.2d 169, 173 (2d Cir. 1947).

108 See United States Fidelity, 683 F.2d at 1025-26 (discussing the Longshoremen's and Harbor Workers' Compensation Act, 33 U.S.C. $\$ \S 901-950$ (1982)).

107 United States Fidelity, 683 F.2d at 1026; see also Sutton v. City of Milwaukee, 672 F.2d 644, 645 (7th Cir. 1982) (a due process case in which Posner used similar reasoning to defend the use of a cost-benefit formula). 
jury or death. Conversely, the burden of precautions, $B$, was moderate to small: the shipowner could have lit the hold, locked the hold door, or posted a warning sign at relatively low cost. ${ }^{108}$ In order for the shipowner to be found not negligent, therefore, the probability of the accident, $P$, would have to be very low.

Posner's argument that $P$ in fact was low provided the major novelty in the case. Posner recognized that the expected behavior of the longshoremen as well as the conditions on the ship would be relevant to the value of $P{ }^{109}$ There was some evidence suggesting that the particular longshoreman who suffered the accident may have entered the dark hold with an intent to steal; in any event, he disregarded the natural warning of darkness, despite the fact that he probably knew that the hatch was open. Posner suggested that only a reckless longshoreman would have entered the hold and that the probability of an accident was therefore low. ${ }^{110}$ Nevertheless, the plaintiff could have attempted "to prove that there are so many reckless dishonest longshoremen as to require the precautions that the defendant in this case would have had to take to avert injury to them."111

Posner has also used a form of cost-benefit analysis to evaluate free-speech rights. In LaFalce v. Houston, ${ }^{112}$ the court, through Posner, held that a city may use political criteria to award public contracts. An unsuccessful bidder had claimed that, when the city based its contract decision on his political views, it infringed his first amendment right to political speech. Comparing the benefits and costs of extended free-speech protection, Posner attempted to distinguish this case from a situation in which a government official fires a public employee for political reasons. ${ }^{113}$ On the benefit side, Posner argued that the oppor-

108 See United States Fidelity, 683 F.2d at 1027.

109 As an academic writer, Posner noted that Judge Hand's formula does not make explicit reference to the possibility of accident avoidance by the victim. See Posner, $A$ Theory of Negligence, 1 J. LeGal STUD. 29, 33 (1972).

${ }^{110}$ See United States Fidelity, 683 F.2d at 1028.

121 Id. Compare Brown, Toward an Economic Theory of Liability, 2 J. LEGAL STud. 323, 333-34 (1973), in which Professor Brown argues that the Learned Hand formula leads to a minimizing of social costs only if the standard of negligence for each party is determined on the assumption that the other party is acting optimally. Brown also argues that, in determining whether or not an injurer is negligent, the cost of completely avoiding an accident should not be compared with the expected accident costs; rather, the marginal cost of an additional unit of accident precaution should be compared with the marginal expected benefits of an additional unit of protection. See id. at 332-33. If the marginal expected benefits exceed the marginal costs, the injurer should be found negligent. Id. Although Posner's analysis may be consistent with Brown's, it is unfortunate that Posner did not take the opportunity to incorporate explicitly Brown's criticisms.

112712 F.2d 292 (7th Cir. 1983), cert. denied, 104 S. Ct. 712 (1984).

113 The Supreme Court has held that discharging a public employee solely be- 
tunity costs of a public employee's loss of a job exceeded the opportunity costs of a government contractor's loss of a bid, because the contractor could find private customers for his services more easily than a public employee could find alternative employment. ${ }^{114}$ Moreover, Posner claimed that, unlike individuals, many business firms support both major parties, and that they do so "not only or mainly because some government contracts are let on a partisan basis."115 Under these circumstances, Posner suggested, requiring the award of contracts of a politically neutral basis would have relatively little effect upon the political activities of firms. ${ }^{116}$ On the cost side, Posner noted the difficulty of eliminating partisanship from government contracting and the dangerous potential for lawsuits whenever government contractors lose their bids. Posner thus concluded that the costs of eliminating patronage exceeded the benefits and denied the expansion of the right to free speech. ${ }^{117}$

Posner's strong preference for a cost-benefit approach to judicial reasoning surfaces most clearly in NLRB v. Browning-Ferris Industries. ${ }^{118}$ In this case, a strike was in progress at the plant of one of BFI's customers, and two BFI truckers refused to cross the picket line. In an opinion by Posner, the court held that the refusal to cross the picket line was a protected activity under the NLRA ${ }^{119}$ but that BFI could permanently replace the truckers without committing an unfair labor practice. ${ }^{120}$ Posner justified classifying the truckers' conduct as protected activity in part by arguing that "[s]uch treatment allows a more flexible comparison of the benefit to the workers and the burden to the employer. To hold such conduct unprotected would allow the employer to suppress it even if its cost to him was trivial."121 Thus, Posner was willing to expand the scope of statutory protection for workers, not because he favored such expansion per se, but because

cause of her party affiliation will violate the first amendment unless the affiliation is "an appropriate requirement" for "effective performance" in her position. See Branti v. Finkel, 445 U.S. 507, 518 (1980).

${ }^{114}$ See LaFalce, 712 F.2d at 294.

115 Id.

116 See id. Posner suggested that requiring the award of contracts on a politically neutral basis would have relatively little effect on the political neutrality of business firms. In Posner's view, they support both major parties not only or mainly because some government contracts are awarded on a partisan basis, but because "the pervasive role of government in modern American life has made it important for business firms to be on good terms with the major political groupings of society." Id.

117 See id. at 294-95.

118700 F.2d 385 (7th Cir. 1983).

11029 U.S.C. $\$ \S 151-169$ (1982).

120 Browning-Ferris, 700 F.2d at $387,389$.

121 Id. at 388. 
such expansion allowed a cost. Denefit approach to determining workers' rights. Once inside the cost-benefit framework, however, Posner had little trouble finding that the employer's burden outweighed the employees' benefit and denying enforcement of the NLRB's order. ${ }^{122}$

\section{Procedure}

Judge Posner's economic theory of procedure represents a specific application of cost-benefit analysis. Instead of comparing the benefits and costs of a given activity, however, the Posnerian theory of procedure analyzes the net effect on the direct costs and error costs of adopting a given procedural rule. ${ }^{123}$ Although Posner's opinions have neither cited his theory of procedure, nor even used the theory's terminology, the reasoning behind the theory nevertheless underlies much of his judicial analysis in the area of procedure. Thus, it will be instructive to examine Posner's opinions in this area from the perspective of his theory.

In Sutton v. City of Milwaukee, ${ }^{124}$ the court of appeals held that a city ordinance that authorized the towing of illegally parked cars without the opportunity for a prior hearing did not violate constitutional rights to due process. ${ }^{125}$ Citing Supreme Court precedent for using costbenefit analysis in procedural due process cases, ${ }^{126}$ Posner compared the expected benefit of the suggested procedural safeguard with the expected cost of the safeguard. The expected benefit identified in the case could be described as "error cost" under Posner's theory of procedure: the value of the property interest at stake multiplied by the probability of government error in determining the parking violation. ${ }^{127}$ Posner argued that the expected error cost was small: the value of the property interest embodied in the use of a car for a short period and the probability of government error in the issuance of parking tickets were both relatively low. On the other hand, Posner claimed that the direct cost of the safeguard would be high. Because a preseizure hearing would be infeasible, the cost, according to Posner, would be the abandonment of towing. Posner therefore concluded that the city's towing policy was cost-justified and did not violate due process. ${ }^{128}$

The most complex and controversial of Posner's opinions on pro-

122 See id. at 388-89.

123 See supra notes 49-56 and accompanying text.

124672 F.2d 644 (7th Cir. 1982).

125 See id. at 648.

128 See id. at 645 (citing Mathews v. Eldridge, 424 U.S. 319, 335 (1976)).

127 See id.

${ }^{128}$ See id. at 646. 
cedure, Marrese v. American Academy of Orthopaedic Surgeons, ${ }^{129}$ involved a contempt charge for failure to obey a discovery order. The plaintiffs, certified orthopaedic surgeons, were denied membership in the defendant association, a private professional group to which most orthopaedic surgeons belong. The plaintiffs first brought suit in state court and lost on their claim that they had a right to a hearing on their application for membership. The plaintiffs then sued in federal court under the antitrust laws. ${ }^{130}$ After the district court denied the defendant's motion to dismiss on grounds of res judicata and failure to state a claim, the plaintiffs began discovery by asking the defendant to produce documents relating to the denial of the plaintiffs' applications. The defendant refused to comply with the discovery request, even after a court order, and the district court held the defendant in criminal contempt. ${ }^{\mathbf{1 3 1}}$ The court of appeals, in an opinion by Posner, overturned the finding of contempt on the ground that the defendant should not be subject to discovery of its membership files prior to discovery of the probable anticompetitive effects of its activities. ${ }^{132}$

In his opinion, Posner first examined the net effect that allowing discovery would have on direct costs. Because the defendant "cared enough to incur a sanction for contempt,"133 Posner inferred that the

128692 F.2d 1083 (7th Gir. 1982) (Marrese I), modified, 706 F.2d 1488 (7th Cir. 1983) (Marrese II), modified on rehearing en banc, 726 F.2d 1150 (7th Cir. 1984) (plurality opinion by Posner, J.) (Marrese III), rev'd, 105 S. Ct. 1327 (1985). Posner wrote three different opinions in the court of appeals' consideration of the Marrese case. In Marrese 1, described in the text following this note, Posner wrote an opinion for the majority of a three-judge panel analyzing the plaintiffs' action under principles of res judicata and antitrust law and concluding that the trial court had abused its discretion by granting discovery of the association's membership files "before there was any discovery on the issue of probable anticompetitive effect." See 692 F.2d at 1092, 1095-96. Later, in an attempt to pre-empt en banc consideration of the case, Posner wrote a second panel opinion whose narrower focus was apparently more acceptable to a majority of the judges in the 7th Circuit. See Marrese II, 706 F.2d at 1492. This second opinion contained no discussion of the res judicata issues in the case. See id. at 1497-98.

Rehearing en banc was eventually granted despite Posner's efforts. See Marrese $I I I, 726$ F.2d at 1152 . By this time, however, the district court had certified the res judicata question for immediate review under section 1292(b) of the Federal Rules of Civil Procedure. See id. Thus, Posner's third opinion analyzed the res judicata issues primarily in connection with the proposed dismissal of the plaintiffs' action rather than in reference to the validity of the district court's discovery order.

Under these circumstances, Marrese $I$ seems to reflect most accurately the full range of issues that Posner was willing to consider in connection with the plaintiffs' discovery request. This Comment therefore analyzes Marrese $I$ instead of the more recent opinions issued in the case.

130 See Marrese I, 692 F.2d at 1087.

131 See id.

192 See id. at $1095-96$.

${ }^{133}$ Marrese I, 692 F.2d at 1088. 
costs to the defendant would be high. He suggested that the defendant's release of its files, even under the terms of a protective order, could lead its members to offer less candid evaluations of future applicants ${ }^{134}$ and therefore inhibit the free exchange of information about beneficial "surgical techniques and related matters of great public interest." ${ }^{135} \mathrm{He}$ also suggested that weakening the confidentiality of voluntary associations might undermine the vital role of these organizations in American society. ${ }^{136}$

Posner neglected to consider the potential decreases in direct costs that would result from upholding the district court's order. ${ }^{137}$ One potential effect that Retired Justice Stewart found compelling was that fewer parties would seek interlocutory review of discovery orders. ${ }^{138}$ By reversing the judgment of contempt, the court "interfere[d] with the District Judge's authority to control the discovery process and encourage[d] the filing of interlocutory appeals in the heavily burdened federal appellate courts."139

Next, Posner considered the net effect that allowing discovery would have on error costs. Discovery would reduce these costs only if it would help the plaintiffs in preparing their case; that is, the only economically justifiable discovery would be that which affected the plaintiffs' likelihood of victory on the merits. Thus, Posner reasoned that he must preliminarily consider the merits of the plaintiffs' case. ${ }^{140}$ If he found the likelihood of victory to be small, burdensome discovery would not be cost-justified.

In this context, Posner proceeded to evaluate whether res judicata would eventually be held to bar the plaintiffs' claim. He concluded, albeit without much help from precedent, ${ }^{141}$ that res judicata should act

134 See id. at 1088-89.

135 Id. at 1088 .

136 See id. at 1089.

137 Posner noted that such discovery might increase the likelihood of settlement, but seemed to discount the value of any savings in direct costs that this would create by noting that

[i]f [the case has no possible merit], the only "value" of the requested discovery will be to give the party seeking it leverage to extort a settlement, by enabling him to impose on his opponent costs that may induce a settlement offer despite the lack of merit of the case.

Id.

138 See id. at 1099 (Stewart, J., dissenting).

199 Id.

140 See id. at 1089.

142 Retired Justice Stewart's dissenting opinion characterized Posner's analysis as "a completely unprecedented expansion of the res judicata doctrine, inconsistent with existing law in several Circuits, including a previous decision of this Court." Id. at 1099. 
as a bar, because forcing future plaintiffs to combine their antitrust claim with their state claim in state court would not increase error costs, ${ }^{142}$ but would effect a net savings in direct costs. ${ }^{143}$

Turning to the antitrust claim, Posner noted that in order to prevail the plaintiffs would have to show that the defendant's actions had an anticompetitive effect. ${ }^{144}$ Because the plaintiffs had not yet shown any anticompetitive effects, and there did not appear to be any net cost savings from allowing the discovery of the defendant's membership files, Posner concluded that discovery on the existence of anticompetitive effects should precede the burdensome discovery ordered by the district court. ${ }^{145}$

Posner has also applied his procedural theory to criminal cases: In United States $v$. Kaminski, ${ }^{146}$ his concurrence advocated a cost-minimizing approach to the analysis of entrapment. The defendant in the case had been looking for work, and he boasted of his abilities as an arsonist to a government informant. The informant put the defendant in contact with an undercover agent, who offered to hire the defendant to burn down a building. The defendant agreed, and he was arrested at the building before he could set fire to it. ${ }^{147}$ In upholding the jury's conviction of the defendant, the court found that the evidence in the case adequately established that the defendant was predisposed to commit the crime and therefore had not been entrapped. ${ }^{148}$ Posner agreed with this analysis but then went on in a concurring opinion to advocate an economic approach to the concept of "predisposition." Claiming that "entrapment" simply denoted a cost-inefficient use of limited law enforcement resources, Posner reasoned that

if the police entice someone to commit a crime who would not have done so without their blandishments, and then ar-

\footnotetext{
142 The best reason for not giving preclusive effect to a judgment in an earlier state court action would be a belief that state courts were not competent to adjudicate federal antitrust questions . . . . But this belief cannot be maintained given that state courts are allowed to decide federal antitrust questions, with preclusive effect under the doctrine of collateral estoppel, in suits in which a federal antitrust claim is raised by way of defense.
}

Id. at 1091.

143 See id. at 1092-93.

144 See id. at 1095.

145 See id. at 1095-96. Posner's pretrial consideration of the merits drew much criticism from Retired Justice Stewart in his dissent. See id. at 1098-99. Stewart's dissent may have persuaded other judges of the court of appeals to insist that Posner rewrite his opinion. See Caplan, supra note 2 , at D4, col. 1.

146703 F.2d 1004 (7th Gir. 1983).

147 See id. at 1005-06.

148 See id. at 1008-09. 
rest him and he is prosecuted, convicted, and punished, law enforcement resources are squandered in the following sense: resources that could and should have been used in an effort to reduce the nation's unacceptably high crime rate are used instead in the entirely sterile activity of first inciting and then punishing a crime. However, if the police are just inducing someone to commit sooner a crime he would have committed eventually, but to do so in controlled circumstances where the costs to the criminal justice system of apprehension and conviction are minimized, the police are economizing on resources. ${ }^{148}$

Thus, entrapment imposes both the direct costs of expenditure of time and effort by law enforcement officials, and the error costs of prosecuting people who would not otherwise commit a crime. Conversely, the activity engaged in by the agents in Kaminski decreased both direct and error costs and therefore was acceptable. Posner insisted that his economic approach would lead judges to base findings of predisposition to commit a crime not on psychological conjecture but on commonsense judgments. ${ }^{150}$

In a fourth case dealing with procedure, Posner faced the problem of deciding whether to enforce a procedural rule that would arguably increase error costs but would decrease direct costs. USM Corp. v. SPS Technologies, Inc., ${ }^{181}$ addressed whether res judicata barred a patent infringer-who had paid royalties to the patent holder pursuant to a consent decree in a patent infringement suit-from seeking recovery of those royalties on the theory that the patent had been fraudulently procured. The court held that the consent decree, in which the infringer had acknowledged the validity and infringement of the patent, prevented the parties from relitigating the patent's validity. ${ }^{162}$ Posner refused to create an exception to the settled rule of res judicata for consent decrees, because "such an exception, rather than deterring patent fraud, would reduce the incentive of an infringer to prove fraud when first sued; he would have nothing to lose by biding his time until the terms of the settlement became onerous to him."16s Evidently, Posner believed that the procedural rule would not increase the error costs of patent fraud substantially, but would decrease greatly the direct costs of

149 Id. at 1010 (Posner, J., concurring).

${ }^{150}$ See id. This argument will be criticized below. See infra note 267.

151694 F.2d 505 (7th Cir. 1982), cert. denied, 462 U.S. 1107 (1983).

262 See id. at 507.

16s Id. at 508. 
extended litigation. ${ }^{154}$ Holding otherwise would, in Posner's view, encourage strategic behavior by civil plaintiffs rather than cost-minimizing litigation activity.

\section{E. Interpretation}

Just as he does with his theory of procedure, Judge Posner employs his theory of statutory interpretation in his opinions without identifying the theory or its academic development. Although his opinions never classify statutes as "interest group" or "public interest,"155 and never term his reasoning as "imaginative reconstruction,"156 Posner implicitly uses these concepts. Thus, it again makes sense to examine these opinions from the perspective of his theoretical framework. Constitutional rights cases, however, present more of a problem: Posner's theory is neither as developed nor as closely tied to economic analysis as are his other theories. A sampling of these cases confirms Posner's reluctance to expand the constitutional rights of individuals but fails to uncover a true economic theory of constitutional rights.

CBI Industries $v$. Horton ${ }^{157}$ offers one example of Posner's theory of statutory interpretation in action. Posner was construing section 16(b) of the Securities Exchange Act of 1934, which requires a corporate director who sells shares in her company and then buys them back at a lower price within six months to return to the company "any profit realized" by her. ${ }^{168}$ The defendant in the case was both a corporate director of CBI and a co-trustee of a trust for the benefit of his two grown sons. As co-trustee, he had no direct pecuniary interest in the trust. The defendant sold 3000 shares of his stock in CBI. Within six months, he bought back 2000 shares of the stock for the trust at a lower price, making a $\$ 25,000$ profit for his sons. ${ }^{169}$ The court of appeals held that unless the trust was a sham the company could not recover the profit. ${ }^{160}$

Writing for the court, Posner admitted that a "person's 'wealth,'

154 Posner noted that "[a]s we are not persuaded that patent fraud will on balance be less common if there is an exception to res judicata for cases in which such fraud is alleged, the general policy in favor of finality of litigation leads us to reject the exception." Id.

${ }^{185}$ See supra text accompanying notes 60-73 (explaining "interest group" and "public interest" classifications).

${ }_{108}^{108}$ See supa text accompanying note 69.

187682 F.2d 643 (7th Cir. 1982).

18815 U.S.C. $\$ 78 \mathrm{p}(\mathrm{b})(1982)$ (governing the treatment of "short-swing" transactions by officers, directors, and large shareholders).

150 See 682 F.2d at 644 .

160 See id. at 647. 
in a realistic though not pecuniary sense, is increased by increasing the pecuniary wealth of his children ... provided only that he has the normal human feelings toward his children." "161 But Posner argued that this "realistic" interpretation would place greater restrictions on corporate insiders than the Congress that enacted the Securities Exchange Act had intended, "when notions of conflict of interest were less exacting than they are today." "162 Such an interpretation would, according to Posner, "impute the morality of the 1980 s to the Congress of the 1930s."163

Implicitly, then, Posner viewed the Securities Exchange Act, or at least section 16(b), as interest group legislation, and therefore felt justified in applying "imaginative reconstruction" to reach his result. If Posner had pasted the "public interest" label on the statute, however, its expressed purpose of preventing unfair use of inside information would probably have mandated the opposite result.

In McDonald v. Schweiker, ${ }^{\mathbf{1 6 4}}$ Posner again implicitly classified a statute as "interest group" legislation and proceeded to divine congressional intent. In this case, however, the outcome would likely have been the same even if Posner had labeled the statute a "public interest" enactment. Posner was interpreting a provision of the Equal Access to Justice Act that enables a successful claimant to obtain an award of attorney's fees in certain cases if the claimant submits the application within thirty days of the "final judgment."165 In Posner's view, "final judgment" in this statute meant the conclusion of all legal proceedings, including appeals, rather than the final decision of the district court. ${ }^{166}$ Although the alternative interpretation would have resulted in a savings in direct costs because appeals on the merits could then be consolidated with appeals of attorney's fees, Posner insisted that "there is no indication that the Congress that enacted the Equal Access to Justice Act was worried about the burdens the Act might place on the courts of appeals."167

According to Posner, the intent of Congress was to make it easier for a plaintiff to bring small claims against the government. ${ }^{168}$ Posner's analysis suggests that he treated the statute as interest group legislation and found that implementing congressional intent outweighed the effi-

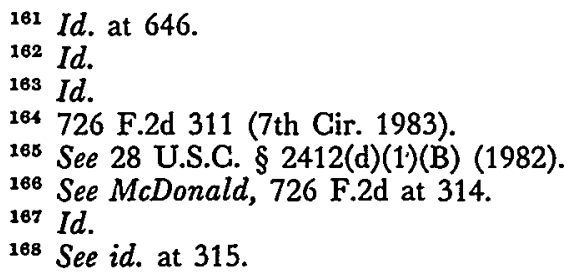


ciency concerns. ${ }^{169}$ Since congressional intent coincided with the ostensible public interest purpose of the statute, however, the interpretation would have been the same regardless of how the statute was classified. ${ }^{170}$

In A.O. Smith Corp. v. United States, ${ }^{171}$ Posner demonstrated a new interpretive technique: replacing "imaginative reconstruction" with imaginative judicial construction. The case involved a corporation that took investment tax credits on certain property but later sold the property prematurely. Under the Internal Revenue Code, the corporation had to treat as taxable income part of the previously taken credits, but the Code did not explicitly state whether the tax on such income must be paid on the "estimated basis" (throughout the year rather than all at the end) used to determine "normal" corporate income tax. ${ }^{172}$ Although the Internal Revenue Code seems an unlikely candidate for the public interest label, Posner treated it that way by ignoring, or by failing to admit the impossibility of determining, congressional intent. ${ }^{\mathbf{1 7 3}}$ Posner instead gave two arguments favoring his interpretation that the corporation had to pay on an estimated basis: a textual argument and a policy argument that firms should not be given the incentive to dispose of investments prematurely.

In dissent, Judge Dumbauld argued that tax statutes should be read literally, and he criticized the "expansive" interpretation that Posner used to order payment on an estimated basis. Judge Dumbauld expressed concern that Posner "carries over into the analysis of this case the philosophy which permeates [Economic Analysis of Law]: that economic activity is a rational decision-making process, aimed at optimizing allocation of resources and minimizing imperfections of the market such as information costs and transaction costs."174

169 To be sure, Posner's interpretation also acted to increase efficiency, as Posner himself acknowledged. First, the cost of filing multiple applications for attorney's fees is eliminated. Second, "giving the claimant a choice whether to ask for fees after he wins in the district court or after the appeal maximizes his welfare, at some cost perhaps to the courts but none we can think of to the executive branch." Id. at 314-15.

170 Posner went on to hold that the claimant did not in fact qualify for attorney's fees, even though her application was timely, because the government had a "solid legal claim." Id. at 316.

171691 F.2d 1220 (7th Cir. 1982).

172 See id. at 1221.

${ }_{173}$ The paucity of legislative history was pointed out by the dissent, see id. at 1225 (Dumbauld, J., dissenting), which went on to reject the corporation's argument that "exemption from prepayment of tax was an intended incidental side effect or 'sweetener' which was part of the 'deal' struck in Congress . . . ." Id.

${ }^{174} I d$. at 1222 . Judge Dumbauld, contending that tax law is based on a different philosophy, stated

that rationality is not to be expected; that logic and justice are irrelevant; 
Although one can square Posner's actual statutory interpretation with his theories without undue straining of plausibility, Posner's interpretation of constitutional rights follows no discernible theoretical pattern other than that of simply denying rights when they are not clearly enumerated in the Constitution. In trying to comport Posner's elusive theory of constitutional interpretation with his opinions, one must decide how the theory would aid a judge in the interpretation of constitutional rights. Arguably, Posner has not offered an interpretive theory at all, merely a general conclusion that individual rights ought to be construed narrowly and a rationalization for that conclusion. In this case, examining Posner's application of his "theory" would be an unrewarding endeavor: in difficult cases, constitutional claimants always lose, period.

On the other hand, Posner's theory may in fact outline a true interpretive analysis. In that case, the interpretation of individual rights must be related to the nature of the action backed by the "will of the majority" or the "dominant power" through some governmental body. If a governmental act only weakly evidences the will of the majority, the utilitarian justification for the act diminishes; likewise, if an act only slightly furthers the self-interest of the dominant power, support for the act becomes politically imprudent. In either case individual rights will receive relatively more protection. The interpretive focus, however, is on the governmental actor rather than on the individual. While this formulation of Posner's theory extrapolates a bit from Posner's own discussion, the extrapolation suggests the most reasonable interpretive methodology with which a Posnerian jurist can grapple. Unfortunately, Posner's judicial performance in the constitutional rights area indicates that, if he has his constitutional theory in mind at all, it is only the conclusion that matters, not the interpretive analysis. Three illustrative cases will serve to point out the interpretive inconsistencies.

First, in Menora v. Illinois High School Association, ${ }^{175}$ the court held that a high school sports association's rule forbidding the wearing of any type of headwear during basketball games did not violate the first amendment rights of orthodox Jews who wanted to wear yarmulkes fastened with bobby pins. Rather than directly analyzing the majoritarian interest in enforcing the safety-oriented rule, Posner

that tax law is "positive law" in the classical sense of that term; and that nothing but the expressed will of the legislator is controlling. The intent of Congress is conclusive. Tax law is a field where arbitrary fiat is king ....

Id.

${ }^{175} 683$ F.2d 1030 (7th Cir. 1982), cert. denied, 459 U.S. 1156 (1983). 
looked to choice-of-law jurisprudence and transplanted the interest analysis technique for resolving conflicts of law in interstate disputes. ${ }^{\mathbf{1 7 6}}$ Because Jewish law did not specifically require that its adherents wear yarmulkes secured by bobby pins, the case presented what conflicts scholars have termed a "false conflict."177 The Jewish basketball players had no "interest" in using this particular headcovering. Thus, the state's safety interest, however slight, automatically prevailed. This conclusion did not, however, mandate dismissal of the case. Posner ordered that the plaintiffs be given an opportunity to propose a form of headcovering that met the safety concerns of the association. Then, "if [the Association] refuses to accommodate the indisputably sincere beliefs of a religious group though it can do so at no cost to the only objective, safety, that the rule in question is claimed to have-it will be standing on constitutional quicksand."178

In a second case, Vail $v$. Board of Education, ${ }^{179}$ Posner in dissent did not even attempt to articulate the majoritarian interest at stake. The court majority held that a school athletic director who was fired

176 See id. at 1033.

177 See, e.g., D. Cavers, The Choice-of-Law Process 89-90 (1965). Advocates of governmental interest analysis instruct courts attempting to determine which law to apply in an interstate dispute "to decide whether, in the light of the respective policies expressed in the laws and of the circumstances of the case, the states involved would have an interest in the application of their respective laws to that issue." See id. at 63. If the interests of only one state would be furthered, there is a "false conflict." Id. at 89. For example, in a wrongful death case, only the defendant's state of domicile has any interest in damage limitations, since such limitations are enacted to protect defendants. If the domiciliary state or the place of injury has damage limitations, and the defendant's home state allows for unlimited damages, there is a false conflict, because no interest of the plaintiff's state or the place of injury will be furthered by the application of its law. See Hurtado v. Superior Court, 11 Cal. 3d 574, 522 P.2d 666, 114 Cal. Rptr. 106 (1974); Reich v. Purcell, 67 Cal. 2d 551, 432 P.2d 727, 63 Cal. Rptr. 31 (1967).

In Menora, Posner applied these choice-of-law principles to constitutional issues. He found that there was no more than a "false conflict" between the individuals" religious beliefs and the regulation. See id. at 1033-34. Although there was a religious obligation to keep the head covered, there was no specific mandate "to wear yarmulkes attached by bobby pins." Id. Therefore, despite the fact that the association was unable to prove that the pinned yarmulkes posed a "substantial safety hazard," see id. at 1034, the state's minimal safety concerns still prevailed, because the individuals had no interest in wearing yarmulkes fastened by bobby pins. See id. at 1035 .

${ }^{178} I d$. at 1034 . This suggestion is somewhat remarkable. As the dissent points out, the National Federation of State High School Associations, which drafted the disputed rule, was specifically asked whether the rule would allow yarmulkes " if they were not attached by bobby pins or other types of clips which could be judged as hazardous." "Id. at 1037. The Federation's response was " No. Since headwear, other than a headband, is illegal the method of attachment is not a concern. If the rules were changed to allow players to wear skull caps, the manner in which they would be attached, or the type of attachment, would be a concern.' "See id. at 1037 (Cudahy, J., dissenting) (emphasis added in opinion).

${ }^{179} 706$ F.2d 1435 (7th Cir. 1983), affd, 104 S. Ct. 2144 (1984). 
after only one year of an alleged two-year employment contract was deprived of property without due process in violation of the fourteenth amendment. ${ }^{180}$ Using conventional legal analysis rather than an economic approach, Posner argued that the plaintiff had no "property" interest at stake, had not been "deprived" of any right, and had no "due process" right to a hearing. ${ }^{181}$ The driving motivation behind Posner's arguments was the existence of an alternative remedy for the plaintiff-a breach of contract suit in state court. Posner did not identify any majoritarian interest in the school board's action, nor is one readily apparent on the facts of the case. ${ }^{182}$ Posner's contention that constitutional rights should be narrowly construed when a sufficient alternative exists may be jurisprudentially sound. It does not harmonize, however, with the theory that Posner has put forth.

Even if one could articulate a utilitarian basis for restricting constitutional rights when a sufficient alternative exists, one would have difficulty explaining Posner's opinion in a third case-Jackson v. City of Joliet ${ }^{183}$-in which Posner articulated neither a majoritarian interest nor an adequate alternative for the plaintiff. Jackson involved an action under section 1983. ${ }^{184}$ The court held that an attempted rescue by state police officers that failed due to the officers' negligence was not a deprivation of life without due process of law under the fourteenth amendment. Here, Posner did not base his argument on utilitarianism. Contending that the Constitution was intended to prevent government oppression rather than provide government benefits, Posner concluded that the plaintiff was the victim of inaction rather than oppression, and thus suffered no constitutional deprivation. ${ }^{185} \mathrm{He}$ suggested that this was an issue best left to state tort law $^{\mathbf{1 8 6}}$ and maintained that there already existed sufficient incentives, through potential political retribution, for police to provide effective service. ${ }^{187}$

The foregoing presentation is a small sample of Posner's constitutional rights cases and is not necessarily meant to indicate the correctness or incorrectness of Posner's results. This section has sought to link

180 See id. at 1438.

181 See id. at 1449-56.

182 Posner did, however, note the absence of significant minority interests: "The Bill of Rights protects the interests of unpopular or vulnerable groups and it is natural to be concerned about their legal remedies. Football coaches do not comprise such a group and Vail makes no claim under the Bill of Rights." 706 F.2d at 1455 (Posner, J., dissenting).

183715 F.2d 1200 (7th Cir. 1983), cert. denied, 104 S. Ct. 1325 (1984).

18442 U.S.C. $\S 1983$ (1982).

18s See id. at 1203-05.

188 See id. at 1203.

187 See id. at 1205. 
the rationales and approaches in Posner's judicial opinions to his economic theories. The last three cases merely suggest that in the area of interpreting constitutional rights, unifying theory and application is impossible.

\section{A Critique of Posnerian Jurisprudence}

The two previous sections have provided the background necessary to analyze in a principled way Posnerian jurisprudence as Posner has applied it from the bench. Because this Comment focuses on Posner's methodology rather than on his conclusions, the Comment does not attempt directly to argue how Judge Posner should have decided particular cases. ${ }^{188}$ Instead, this section reviews Posnerian jurisprudence from two overlapping perspectives: first, Posner's use of his theories in his opinions, and, second, the value of Posner's theories themselves as tools for judicial decisionmaking.

\section{A. Criticisms of Application: Posner the Jurist}

One overall criticism of Judge Posner's application of the economic analysis of law that emerges from studying his opinions is that Posner has applied his theories in a manner that has promoted a conservative political ideology at least as much as it has advanced an economic methodology. Posner previously has confronted this criticism with respect to his theories themselves. ${ }^{189}$ In that context, his response has been that economic analysis of law supports liberal as well as conservative positions. ${ }^{190}$

This response does not meet the present criticism. First, the fact that Posner's application of economic analysis may support some liberal positions does not necessarily clear Posner of political bias in his application. Second, the criticism applies not to Posner's conclusions, per se, but rather to the reasoning leading up to the conclusions.

The criticism is not that judges should, or even can, refrain from adopting a political ideology, or that conservative political ideology is wrongheaded. Rather, the criticism is that, instead of applying the the-

${ }^{188}$ Readers are invited to draw their own conclusions. It should be reiterated, however, that many of the cases discussed were chosen in part because the results are somewhat controversial. This fact does not make the cases any less legitimate as objects of study. Quite the opposite is true, for if economic analysis of law always yielded results that could also be obtained using some other jurisprudential method, the study of this approach would be purely academic and not very satisfying.

189 See R. POSNER, supra note 22, at 21-22.

190 See id. at 21 (general proposition), 349-51 (elimination of poverty), 354-55 (the impact of pay television on the poor), 546-48 (fairness doctrine). 
ory as a conservative advocating a new methodology for general judicial use, Posner has applied the theory primarily to support his conservative ideology. If Posner's response is that judges must necessarily present their opinions in the best possible light without acknowledging their limitations, then he must cease to be viewed as a role model for the law and economics methodology in judicial decisionmaking: increased acceptance of any new methodology depends upon careful, well-reasoned, and consistent use of the applicable theory. If Posner's response is that economic analysis of law necessarily implies a conservative political ideology, then the reader must evaluate that contention against the evidence presented in this Comment.

As has been noted, Posner has used economic analysis explicitly in only a small fraction of his opinions. ${ }^{191}$ If Posner advocated the economic approach in his opinions as forcefully as in his academic work, explicit references to law-and-economics principles would appear more often. In addition, when Posner does employ economic analysis, he does not always state clearly that he is using it, when and how it is appropriate to use it, or what its limitations are. Although these facts are susceptible to several interpretations, ${ }^{192}$ they tend to suggest an intent

101 See supra note 81 and accompanying text.

192 One such interpretation is that Posner is starting off cautiously in order to prove his competence as a judge and perhaps to enhance his chances of nomination to the Supreme Court. Posner has explained his behavior on the bench in the following way:

[I]t would be quite wrong to imagine that a professor would become a judge in order to smuggle into the judicial reports the ideas he had developed as a professor, or that having become a judge, for whatever reason he had done so, he would then set about to see how much of his academic writing he could as it were enact into positive law. He will want to be thought a good judge, and he will not if he uses his position to peddle his academic ideas. ... [I]t will be hard for the judge, whatever his background, to superimpose the very different role of the law professor. And it will be quite silly and futile anyway, unless he happens to be a Supreme Court justice, because less attention is paid to opinions of lesser judges than is paid to books and major articles.

Posner, Wealth Maximization and Judicial Decision-making, 4 INT'L REv. L. \& ECoN. 131, 131 (1984).

Posner's statement, unfortunately, does not explain his performance on the bench. Using economic methodology in appropriate cases clearly can be consistent with being a "good judge." In fact, Posner has used economic analysis in many of his opinions. This Comment criticizes Posner not because he has used economic methodology too frequently, but rather because he has often failed to use the methodology carefully and consistently. Moreover, Posner's reference to the unique ability of a Supreme Court Justice to "peddle academic ideas" seems disingenuous. By virtue of his academic reputation and his status as a frontrunner for Supreme Court nomination, Posner already enjoys a wide audience for his opinions. The reference invites, but does not address, perhaps the most topical question surrounding Posner's tenure as an appellate judge: how much of the economic methodology, including Posner's particular theories, would Posner attempt to enact into law were he to reach the Supreme Court. 
to use economic analysis of law to serve a narrower purpose than merely to advocate a new methodology for judicial decisionmaking.

\section{Selective Use of Economic Analysis}

One argument that supports the criticism that Posner applies economic analysis nonneutrally is that he has failed to introduce it in several cases in which its use could have led to a conclusion that he would not have liked. For example, in United States $v$. Ely, ${ }^{193}$ a judge appointed counsel to an indigent defendant who had been indicted for selling cocaine. The judge then denied a request from the defendant to substitute another lawyer whom the defendant had brought with him and who had agreed to serve as his appointed counsel. The court of appeals, through Posner, held that the denial did not violate the defendant's sixth amendment right to counsel. Posner claimed that the sixth amendment "seeks not to maximize free choice of counsel but to prevent anyone from being unjustly convicted or illegally sentenced."194

Posner's theory of procedure, however, seems to support giving the defendant the counsel of his choice in this situation. Choice of counsel would not add to direct costs, because the substitute counsel was present and had already agreed to serve. ${ }^{195}$ In addition, although Posner maintained that there was no indication that the defendant would do any better with his preferred counsel, ${ }^{196}$ it does not seem an unreasonable inference that a lawyer with whom the defendant was comfortable might reduce error costs if the defendant were innocent and even perhaps if he were guilty. If Posner had used economic analysis, the minimal costs, coupled with the benefits as the defendant perceived them, would seem to require allowing the defendant his choice of counsel, at least in this somewhat unusual case.

In a second case, People Organized for Welfare and Employment Rights (P.O.W.E.R.) v. Thompson, ${ }^{197}$ Posner addressed the question of standing to bring suit in federal court. P.O.W.E.R., a group formed to

193719 F.2d 902 (7th Cir. 1983), cert. denied, 104 S. Ct. 1313 (1984).

194 Id. at 904-05. Although such a statement is consistent with Posner's view that individual constitutional rights should be narrowly construed, see supra text accompanying note 77, it seems flatly inconsistent with his analysis in other cases. Cf. McDonald v. Schweiker, 726 F.2d 311, 314-15 (7th Cir. 1983) (Maximizing the welfare of plaintiffs in civil cases-by allowing them to choose at what point in the litigation to apply for attorneys' fees-is a legitimate concern.).

195 Posner was concerned that allowing indigent defendants to have their choice of appointed counsel would interfere with the trial judge's rotation system for handling the appointment of counsel. See Ely, 719 F.2d at 905.

${ }_{106}$ See id.

197727 F.2d 167 (7th Gir. 1984). 
increase the political power of the poor, asked the state to allow the city's election commissioners to register voters in waiting rooms of public aid offices. The state refused P.O.W.E.R.'s request, and P.O.W.E.R. brought suit under section 1983, ${ }^{198}$ charging a violation of the first amendment. ${ }^{199}$ The court held, using traditional analysis, that P.O.W.E.R. did not have standing to litigate the constitutional question because all of its members were registered to vote. ${ }^{200}$

If Posner had applied his economic theory of procedure, he would have concluded that the court's strict standing rule would minimize error costs only if there were no actual injury or controversy, and would in fact increase direct and error costs if the suit were brought again. ${ }^{201}$ It is in the interest of the indigent nonregistrants and-if society is to use majority voting as the basis for public decisions-in the public interest to facilitate the registration of indigents. All that P.O.W.E.R. needs to do to comply with the court's standing requirement is to enlist several nonregistered indigents and then bring suit. Thus, while some "ideological" suits may amount to little more than "passionate commitment plus money for litigating," 202 P.O.W.E.R.'s suit was clearly costefficient. Standing should have been conferred under a Posnerian procedural analysis.

Finally, in Analytica, Inc. v. NPD Research, Inc., ${ }^{203}$ Posner had his economic theories thrown back at him by dissenting Judge Coffey. In this case, Malec, a co-owner of NPD, retained a lawyer to negotiate a stock transfer from the company to Malec. Subsequently, Malec left NPD, and his wife founded a rival company, Analytica. Analytica brought an antitrust suit against NPD, retaining the same law firm that Malec had used for the stock transfer. The district court disqualified the law firm, and the court of appeals, through Posner, upheld the

\footnotetext{
19842 U.S.C. § 1983 (1982).

199 See 727 F.2d at 168-69.

200 See id. at 173.
}

201 This reasoning is similar to Posner's analysis in United States v. Kaminski, 703 F.2d 1004 (7th Cir. 1983). See supra text accompanying notes 146-50. Concurring in Kaminski, Posner urged a doctrine of entrapment that would convict defendants who were "just induc[ed] . . . to commit sooner . . . crime[s] [they] would have committed eventually," but acquit those who were induced to take actions they would not otherwise have taken. Id. at 1010 (Posner, J., concurring). Posner deemed the latter category a waste of scarce police resources, while the former was cost-efficient and thus permissible. Similarly, it is cost-efficient to grant standing in cases in which injury is known to exist, even if it has not been suffered by the plaintiffs before the court. Granting standing would be a waste of scarce judicial resources only when there is no possible plaintiff because no conceivable injury has occurred.

${ }^{202}$ P.O.W.E.R., 727 F.2d at 172.

${ }^{203} 708$ F.2d 1263 (7th Cir. 1983). 
decision. ${ }^{204}$

In dissent, Judge Coffey argued that the law firm should have been given a chance to rebut the presumption of partiality. Countering Posner's argument that clients would not trust law firms that switch sides so readily, Coffey responded that "[i]f we accept this as true, the 'test of the market' and the law of economics will prevail. A fair and just result will be obtained since the concerned client will select other counsel if he does not trust the present firm."20s If a law firm violated the trust of one of its clients, it would lose not only that client, but also other current clients as well as potential future clients. Thus, economic analysis of law firms' incentives not to violate their clients' trust leads to the conclusion that the presumption of partiality should not be irrebuttable.

\section{Failure to Acknowledge Limitations of Analysis}

Once Posner decides to use his economic analysis, he does not always state the limitations of the methodology. One example of Posner's nonneutral application is his readiness to assert the existence of competitive markets without acknowledging and analyzing the possible presence of market failure. For instance, in Merritt v. Faulkner, ${ }^{208}$ Posner assumed a well-functioning market for transactions between civil lawyers and indigent prisoners. ${ }^{207}$ However, the high degree of external and internal regulation of the legal profession means that contingency-fee arrangements may not be perfectly flexible. These restrictions tend to exclude from the market prisoners and lawyers who would be willing to bargain for a fee either below or above the customary "one-third of settlement" rule. In addition, there is the potential problem of asymmetric information between prisoner and lawyer. Even if, as Posner suggested, judges supplied prisoners with names of lawyers, the prisoners are not in a strong position to evaluate the quality of these lawyers. Likewise, the lawyers might have difficulty determining the value of the prisoners' cases, because the prisoners will have an incentive to exaggerate their worth until the lawyers commit themselves to representation.

Similarly, Posner unquestioningly assumed well-functioning mar-

204 See id. at 1266, 1269.

205 Id. at 1278 (Coffey, J., dissenting) (citing Merritt v. Faulkner, 697 F.2d 761, 769 (7th Cir. 1983) (Posner, J., concurring in part and dissenting in part), cert. denied, 104 S. Ct. 434 (1984)).

${ }^{208} 697$ F.2d 761 (7th Cir. 1983), cert. denied, 104 S. Ct. 434 (1984) (discussed supra text accompanying notes 84-88).

207 See id. at 769-71 (Posner, J., concurring in part and dissenting in part). 
kets in order to apply the Coase Theorem in United States Fidelity $\mathcal{E}^{\circ}$ Guaranty Co. v. Jadranska Slobodna Plovidba ${ }^{208}$ and Powers $v$. United States Postal Service. ${ }^{208}$ In United States Fidelity, Posner claimed that the reflection of expected accident costs in the fee paid to the stevedore meant that the shipowner had an incentive to undertake all cost-efficient accident prevention measures. ${ }^{\mathbf{2 1 0}}$ Posner never inquired whether the shipowner had any monopsony ${ }^{211}$ power or whether there would be any difference in the stevedore's and shipowner's views on the probability of an accident. It could be that the stevedore simply never considered the possibility of someone falling in the dark hold and so never bargained for a higher wage; that is, the stevedore could have acted "irrationally" from an economic viewpoint. Alternatively, the transaction costs of ascertaining the relevant costs and probabilities could have prevented the installation of lights in the hold or more warning signs.

In Powers, Posner argued that the tenant's rent reflected the landlord's legal right of ejectment. ${ }^{212}$ Again, however, he gave no indication why he thought the rental market worked well in this case. ${ }^{213}$ The markets in United States Fidelity and Powers in fact might have worked well enough for an appropriate application of the Coase Theorem; however, Posner's failure to inquire about possible market imperfections detracts from the strength of his argument and the effective use of his theory.

In addition to ignoring possible market imperfections, Posner has often failed in other ways to complete his analysis. When applying market theory in general and the Coase Theorem in particular, for example, one must recognize that competitive markets do not ensure a proper distribution of income. Under the Coase Theorem, even though the initial assignment of property rights makes no difference with respect to the allocation of resources, the assignment may affect income distribution. ${ }^{214}$ Yet, in Powers, Posner maintained that applying federal common law to a landlord-tenant dispute involving the Postal Service "would merely shift some of the cost of postal service from the users of

${ }^{208} 683$ F.2d 1022 (7th Gir. 1982).

209671 F.2d 1041 (7th Cir. 1982).

210 See supra text accompanying notes 94-100.

211 A monopsonist is a firm that is the only buyer in a given market. It is the counterpart of a monopolist, a firm that is the only seller in a given market.

${ }^{212}$ See supra text accompanying notes 101-04.

213 Posner's analysis "neglects the 'imperfections' (better, the details) of market adjustments some of which relate to this specific lease being a standardized contract drawn up not by the lessor . . . but by the lessee, in this case the United States Postal Service." Samuels \& Mercuro, supra note 1, at 121 (footnote omitted).

214 See supra note 29. 
the mails and from the federal taxpayers to . . landlords. No net increase in the nation's welfare can be assumed from so random a change in the distribution of the costs of postal service." 215 That claim may or may not be true, but applying the Coase Theorem requires a judge to make a distributional choice as part of the final assignment of rights. Posner should not be able to beg off this difficult choice simply by labeling it "random."

\section{Unsupported Empirical Assumptions}

If the conclusion drawn from a theory depends on the satisfaction of certain empirical conditions, an application of the theory that simply assumes that certain conditions hold is incomplete. Posner's opinions often do not indicate when empirical assumptions are made. For example, Posner's conclusion in Sutter $v$. Groen ${ }^{216}$ - that simplifying legal rules by expanding liability will rarely result in a net cost savings ${ }^{217}$-is suspect. Posner neither states nor attempts to verify the key condition, that demand for litigation is elastic, that is, responsive to changes in price.

LaFalce v. Houston ${ }^{\mathbf{2 1 8}}$ is another case in which Posner merely asserts an empirical result that is necessary to his theoretical analysis. In LaFalce he argued that a federal employee would derive greater benefit from constitutional protection than a government contractor, because the contractor could more easily sell its services in the private sector. ${ }^{219}$ Although this fact may be true in some cases, perhaps even in LaFalce, it is surely not always true, ${ }^{\mathbf{2 2 0}}$ and Posner does not support his assertion with any evidence.

In a number of cases, alternative empirical assumptions may lead to results that are entirely different from those reached by Posner. For example, in United States Fidelity, Posner, using the Learned Hand formula, found that $B$, the burden of precautions, exceeded $P L$, the probability of an accident times the magnitude of loss, and therefore concluded that the shipowner was not negligent. ${ }^{221}$ Alternative assumptions would have yielded a different result. The value of a life, $L$, based

215671 F.2d at 1044.

${ }^{216} 687$ F.2d 197 (7th Cir. 1982).

217 See supra text accompanying notes 89-92.

${ }^{218} 712$ F.2d 292 (7th Gir. 1983), cert. denied, 104 S. Ct. 712 (1984).

219 See supra text accompanying note 114.

220 For example, defense contractors would presumably have a much tougher time than government secretaries finding a private market for their services.

221 See supra text accompanying notes 105-11. Actually, Posner held that a jury could reasonably have found the shipowner not negligent, but it is evident from Posner's opinion that he agreed with the jury's determination. See 683 F.2d at 1029. 
on expected earnings, can be postulated conservatively to be $\$ 500,000,{ }^{222}$ and the probability of the accident, $P$, to be .0001 . If the shipowner could have taken additional safety precautions for less than fifty dollars, then he should have done so. The shipowner presumably could have hung warning signs or lights in the hold or locked the hold door for less than fifty dollars. Hence, Posner's conclusion seems open to question if these estimates of $P$ and $L$ are within reason.

A second example of the sensitivity of economic analysis to empirical assumptions may be found in USM Corp. v. SPS Technologies, Inc., ${ }^{223}$ which upheld the application of res judicata to consent decrees. ${ }^{224}$ Posner had argued that an exception for consent decrees would not be cost-justified because, "rather than deterring patent fraud, [such an exception] would reduce the incentive of an infringer to prove fraud when first sued."225

Posner's conclusions depend on several unverified assumptions. Posner assumes that the patent owner's demand for fraudulent activity is inelastic with respect to price and that the patent infringer's demand for litigation is elastic. Both assumptions are questionable. First, Posner does not suggest any reason why an increased likelihood of punishment would not deter a patent owner from engaging in fraudulent activity. Moreover, if there would be at least some deterrence by allowing the reopened litigation, error costs would be reduced, and these cost savings could easily exceed the savings from maintaining the res judicata rule. Second, a patent infringer would not respond significantly to Posner's res judicata rule if it had no reason at the time of the first suit to suspect that the patent at issue was fraudulent. Posner did not indicate the basis for his belief that a patent infringer could ordinarily make this determination.

Even if the patent infringer knew of the fraud at the time of the first suit, it is not clear that it would necessarily take the settlement and "bide its time" for a later challenge to the patent. The patent infringer deciding whether to settle now and sue later or to litigate now would compare the benefits and costs of each alternative. It can be assumed that the expected discounted benefits from the use of the patent are the same under each alternative. ${ }^{228}$ The relevant costs will be either the

222 See, e.g., W.K. VISCUSI, RISK BY CHOICE 101 (1983) (noting estimates of the value of life ranging from $\$ 500,000$ to $\$ 4,000,000)$.

${ }^{223} 694$ F.2d 505 (7th Cir. 1982), cert. denied, 462 U.S. 1107 (1983).

224 See supra text accompanying notes 151-54.

225694 F.2d at 508.

${ }^{228}$ Future benefits and costs must be discounted according to the present value formula: $P V=B /(1+r)^{n}$, in which $B$ is the future benefit (cost), $r$ is the discount rate (the opportunity cost of present furnds, or the "interest rate"), and $n$ is the number 
present settlement costs plus future discounted trial costs or simply present trial costs. There is no strong reason to think $a$ priori that total costs will be different under the two alternatives. Posner's insistence, therefore, that the patent infringer "would have nothing to lose by biding [its] time"227 depends upon the infringer's ability to recover the full amount of the royalties paid out in a subsequent suit. From the perspective of the infringer making a decision, however, the expected future damage recovery must be discounted by both the prevailing discount rate and the probability of success; moreover, the probability of success will likely decrease over time as the evidence in the case becomes increasingly stale. Thus, it would not be unreasonable to conclude that the infringer would ordinarily be better off going to trial immediately; Posner's fears of excessive delay seem exaggerated. ${ }^{228}$

\section{Problems of Definition}

A number of cases call into question Posner's identification of the proper focus for his economic methodology. In cost-benefit cases, for example, initial decisions about what to include as the relevant costs and benefits are often at least as significant as the subsequent analysis. ${ }^{229}$ In Sutton v. City of Milwaukee, ${ }^{230}$ Posner argued that finding a right under the due process clause not to have one's car towed without a notice or hearing would impose not only the cost of the notice or

of years to be discounted. The basic intuition behind the formula is that $\$ 1$ today is worth more to an individual than $\$ 1$ tomorrow, because one can take today's dollar, invest it, and have more than $\$ 1$ tomorrow.

${ }^{227}$ USM Corp., 694 F.2d at 508. See supra text accompanying note 153.

228 Suppose that the present value of the benefits of using the patent equals $\$ 100,000$ and trial costs total $\$ 10,000$ under each alternative. If the infringing company settles now, however, it will have to pay $\$ 40,000$ in royalties, which it will later claim as damages. Assume further that the probability of winning at trial is .8 if the infringer goes to trial now but drops to .5 if the infringer waits. Finally, assume that the discount rate is .05 and the infringer expects to sue in five years. Then the expected value of going to trial now is

(benefits $\times$ probability of winning) - costs

or

$(\$ 100,000 \times .8)-\$ 10,000=\$ 70,000$.

The expected value of the settlement-trial combination is

(benefits - royalties) + (expected damages - trial costs) (discounted)

$\begin{aligned} & \text { or } \\ & (\$ 100,000-\$ 40,000)\end{aligned}-[(\$ 40,000)(.5)-\$ 10,000](1 / 1.05)^{5} \approx \$ 67,835$.

Thus, the rational infringer will go to trial immediately.

${ }^{229}$ See Samuels \& Mercuro, supra note 1, at 114 ("Inevitably selective use of costs and benefits . . . is a subtle means of judicial creativity.") (internal cross-reference omitted).

${ }^{230} 672$ F.2d 644 (7th Cir. 1982). 
hearing, but also the cost of abandoning towing. ${ }^{231}$ It is not clear, however, why the cost of abandoning towing should be considered the relevant opportunity cost. Warning notices could easily be placed on street signs or on offending vehicles themselves for a short period of time without rendering towing infeasible. Even if the city must abandon towing, the opportunity cost might not be very high if practicable substitutes such as wheel locks existed and accomplished the same purpose.

In NLRB v. Browning-Ferris Industries, ${ }^{232}$ Posner found what was arguably a benefit to employees in honoring the picket line of another company. ${ }^{233}$ In contrast, Judge Coffey's concurrence did not find that such activity offered any economic benefit to the workers. $\mathrm{He}$ argued that " [w]orking class solidarity is at best a political slogan, not a viable economic theory." "234

Finally, in Marrese v. American Academy of Orthopaedic Surgeons, ${ }^{235}$ Posner faced judicial scorn when he discounted certain benefits and excluded certain costs in determining whether to uphold the district court's burdensome discovery order. ${ }^{236}$ In particular, he did not consider that striking down the district court's discovery order would increase direct costs by encouraging more parties to seek interlocutory review of discovery orders by the courts of appeals. ${ }^{237}$ In addition, he discounted the benefits of the discovery order by the likelihood that the plaintiffs would ultimately prevail on the merits. The determination of this likelihood led Posner into an extensive discussion of the merits before the case ever went to trial. ${ }^{238}$ In his dissent, Retired Justice Stewart argued that Posner's decision to determine the probability of the plaintiff's receiving the benefits changed the focus of the opinion and "disregard[ed] long-settled principles of civil procedure."239 Eventually, Posner was compelled to remove this argument from the opinion

231 See supra text accompanying notes 124-28.

$2 s 2700$ F.2d 385 (7th Cir. 1983).

${ }^{233}$ See supra text accompanying notes 127-31. This holding represents one of the "liberal" stands that Posner has taken using economic analysis. Even in this case, however, the workers were not ultimately protected; Posner held that they could be permanently replaced. See 700 F.2d at 388-89.

${ }_{234}$ Browning-Ferris, 700 F.2d at 391 (Coffey, J., concurring) (quoting Haggard, Picket Line Observance as a Protected Concerted Activity, 53 N.C.L. REv. 43, 98 (1974)).

${ }^{295} 692$ F.2d 1083 (7th Gir. 1982) (Marrese I), modified, 706 F.2d 1488 (7th Cir. 1983) (Marrese II), modified on rehearing en banc, 726 F.2d 1150 (7th Cir. 1984) (plurality opinion by Posner, J.) (Marrese III), rev'd, 105 S. Ct. 1327 (1985).

${ }^{238}$ See supra text accompanying notes 129-45.

237 See supra text accompanying note 138.

238 See supra text accompanying note 140.

${ }^{230}$ Marrese I, 692 F.2d at 1098 (Stewart, J., dissenting). 
and thus narrow the holding. ${ }^{240}$

Similarly, in the Posnerian theory of statutory interpretation, the initial classification of the statute as "public interest" or "interest group" legislation represents a critical part of Posner's analysis. ${ }^{241}$ In two of the statutory interpretation cases discussed above, a strong argument can be made that Posner misclassified the statutes in order to reach his desired results. In CBI Industries $v$. Horton, ${ }^{242}$ Posner analyzed section 16(b) of the Securities and Exchange $\mathrm{Act}^{243}$ as if it were interest group legislation. ${ }^{244}$ The provisions of the Securities and Exchange Act restricting insider trading, however, serve to correct the market failure of asymmetric information between insiders and outsiders; thus, these provisions seem to constitute public interest legislation, which must be interpreted to meet the problem addressed. Posner gave no justification for reading the statute as if it were a compromise forged by competing interest groups. ${ }^{245}$ Under the public interest method of interpretation, however, the profit realized by a father for his sons' trust funds could easily be found to fall within the statute's prohibition.

In A.O. Smith Corp. v. United States, ${ }^{246}$ Posner analyzed the Internal Revenue Code as if it were public interest legislation. ${ }^{247}$ It is hard to imagine a statute more deserving of the interest group label. Yet interest group analysis does not support Posner's actual approach-extrapolating from the Code a requirement that returned investment tax credits be paid on an estimated basis. Posner's charge of perverse incentives ${ }^{248}$ would carry little weight under an interest group analysis, which Judge Dumbauld implicitly adopted in his articulated philosophy of narrow tax law interpretation. ${ }^{\mathbf{2 4 8}}$

\section{B. Criticisms of Methodology: Posner the Theorist}

Although the above criticisms may expose Posner's underlying

240 See Marrese II, 706 F.2d at 1492.

241 See supra notes 60-73 and accompanying text.

242682 F.2d 643 (7th Cir. 1982).

24315 U.S.C. $\S 78 \mathrm{p}(\mathrm{b})(1982)$.

244 See supra text accompanying and following notes 157-63.

245 Even under Posner's classification of the statute in the interest group category, it is not obvious that Posner's result follows. How does viewing an increase in the sons' wealth as an increase in the father's wealth impute the "morality of the 1980s to the Congress of the 1930s"? 682 F.2d at 646. Could not the Congress of the 1930's, with its traditional notions of family, have intended to link the well-being of children with the well-being of their parents?

246691 F.2d 1220 (7th Cir. 1982).

247 See supra text accompanying notes 171-74.

248 See 691 F.2d at 1222.

248 See id. (Dumbauld, J., dissenting). 
purpose and ideology, their main purpose is to illuminate several weaknesses of the economic analysis of law as a method of judicial reasoning. ${ }^{250}$ For example, the difficulty in making the empirical and practical determinations necessary to apply economic theory ${ }^{251}$ makes this methodology a costly one. Moreover, proper execution of this analysis requires the use of empirical data that is largely unavailable. ${ }^{252}$ Absent sufficient data, the analysis does not yield determinate results. ${ }^{253}$ This weakness might not trouble Posner, for it is often this very indeterminacy that allows him to ground his desired outcomes in economic analysis. This use of economic analysis is not necessarily problematic, but Posner's tendency to write as if economic analysis leads ineluctably to his results does merit attention and criticism by the legal community. ${ }^{254}$

250 Complementing Posner's often repeated references to the growth of the field of economics and the law is a growing body of literature criticizing the field. See, e.g., Gellhorn \& Robinson, The Role of Economic Analysis in Legal Education, $33 \mathrm{~J}$. LEGAL EDUC. 247 (1983) (noting that economic analysis within the legal curriculum is still in its infancy and predicting difficulties in the growth of economic analysis in the classroom); Michelman, A Comment on Some Uses and Abuses of Economics in Law, 46 U. CHI. L. REv. 307 (1979) (criticizing Posner's use of an efficiency criterion in his theories on judicial decisionmaking) [hereinafter cited as Michelman, Uses and Abuses of Economics]; Michelman, Reflections on Professional Education, Legal Scholarship, and the Law and Economics Movement, 33 J. Legal Educ. 197 (1983) (arguing that law-and-economics scholarship is limited in its ability to address certain important fields of legal research); Williamson, Intellectual Foundations: The Need for $a$ Broader View, 33 J. LEGAL EDuc. 210 (1983) (arguing that the field of law and economics relies too heavily on rudimentary price theory); Samuels, Maximization of Wealth As Justice: An Essay On Posnerian Law and Economics as Policy Analysis (Book Review), 60 Tex. L. Rev. 147 (1981) (asserting that Posner's maximization-ofwealth theory is circular in explaining common law development and provides incomplete guidance on issues of rights or policy). Not surprisingly, Posner has kept pace with criticisms of the law-and-economics methodology. For a summation of some of his major responses, see R. POSNER, supra note 22, at 19-23.

281 See supra notes 37-38 and accompanying text; see also Michelman, Uses and Abuses of Economics, supra note 248, at 308 (referring to Posner's "burden of defending against attacks on the empirical reliability of microeconomic theory itself").

262 See Hansmann, The Current State of Law-and-Economics Scholarship, $33 \mathrm{~J}$. LEgal Educ. 217, 231 (1983).

${ }^{253}$ Id.; $c f . i d$. at 234 (comparing Posner's demonstrations of the efficiency of common law to psychoanalytic interpretations of neurosis and noting that "you can always tell a story; but then, given the large number of unobserveable or unmeasureable variables involved, somebody else can always tell a different story"). But $c f$. Samuels \& Mercuro, supra note 1, at 112 ("The problem is not that we do not have the data with which to use wealth maximization. The problem is that wealth maximization does not and cannot itself (even with complete data) determine rights.").

${ }^{284}$ Posner has occasionally acknowledged the limitations of economic analysis. See, e.g., O'Shea v. River Way Towing Co., 677 F.2d 1194, 1201 (7th Cir. 1982) (opinion by Posner) (upholding the computation of future earnings in a tort case: "[W]e recognize that the exactness which economic analysis rigorously pursued appears to offer is, at least in the litigation setting, somewhat delusive."); supra note 107 and accompanying text (referring to limitations on the use of Judge Learned Hand's formula for determining negligence). In general, however, he appears to believe that economic analysis is superior to any other methodology. See, e.g., R. POSNER, supra 
The methodology suffers not only from indefiniteness, but also from incompleteness. Economic analysis of law subsumes the deficiencies of economic theory in general: the theory has very little to say about the related questions of income redistribution, equality of opportunity, and political power. This weakness most vividly appears in Posner's theory of constitutional interpretation. Basing his theory on "utilitarian notions" and "political prudence,"255 Posner unsuccessfully gropes for a logical, practical economic justification for a narrow reading of individual constitutional rights. It is no surprise that Posner's theory is not helpful to the determination of constitutional rights cases: constitutional rights have little to do with economics because they primarily concern equity rather than efficiency. Economic theory simply does not compel the view that the will of the majority or the status quo should determine the distribution of income and political power in society. ${ }^{258}$ The Supreme Court has recognized that protecting individual rights would often thwart the will of the majority or upset the status quo, yet it has held that these protections are necessary because of the uncertain legitimacy of the existing power structure. ${ }^{257}$

Economic analysis also tends to disregard the distributional questions in a specific case at hand. To the economist, past losses are "sunk costs." Economic analysis of law therefore tends to be uninterested in remedying individual losses, and instead concentrates on future, aggregate effects that may result from a present rule of law. ${ }^{258}$ As a result, a thorough legal analysis often requires examining conceptions of justice other than efficiency. Posner often fails to do so, however. In Merritt $v$. Faulkner, ${ }^{259}$ for example, Posner relied exclusively on market considerations to determine that an indigent prisoner should not be represented by appointed counsel in his civil rights suit. ${ }^{260}$ Although it could be argued that appointing counsel in such a case is inefficient but meets equity concerns, ${ }^{261}$ Posner's analysis was limited to questions of effi-

note 22 , at 15-23; Posner, supra note 39 , at 1121 .

${ }_{250}$ See supra text accompanying notes 74-79 (discussing Posner's approach to constitutional analysis).

${ }_{258}^{25 e e}$ supra note 4 (citing alternative conclusions reached by other law-andeconomics theorists).

${ }^{267}$ See, e.g., United States v. Caroline Prods. Co., 304 U.S. 144, 152 n.4 (1938) (" $[\mathrm{P}] \mathrm{rejudice}$ against discrete and insular minorities may be a special condition, which tends seriously to curtail the operation of those political processes ordinarily to be relied upon to protect minorities, and ... may call for a . . more searching judicial inquiry.").

${ }^{208}$ See R. Posner, supra note 22, at 18-19.

288697 F.2d 761 (7th Cir. 1983), cert. denied, 104 S. Ct. 434 (1984). part).

${ }^{200}$ See 697 F.2d at 761, 769-70 (Posner, J., concurring in part and dissenting in 261 For example, contingent fees are often based on the size of the potential recov- 
ciency. In this way, Posner's opinions often lend an illusion of completeness to the economic analysis of law.

Posner himself has implicitly recognized the insufficiency of the efficiency criterion of justice, at least in the realm of constitutional rights. In his academic work, he has relied upon "utilitarian notions" and "political prudence" to articulate alternative conceptions of justice. ${ }^{202}$ In his judicial work, he has delimited constitutional rights on the basis of political philosophy, ${ }^{263}$ political science, ${ }^{264}$ and even a "sense of justice."285

\section{The Proper Role of Economic Analysis in Judicial DECISIONMAKING}

Posner correctly argues that the characteristics of indeterminacy and incompleteness do not mean that economic analysis is a useless judicial methodology. ${ }^{266}$ In light of the foregoing discussion, however, the overall value of economic analysis and the ways in which it can best be improved should be considered. Much of this assessment can be made by evaluating the differences between economics and traditional jurisprudence.

ery, which in many tort cases depends largely on lost earnings. Therefore, regardless of the merits of their cases, claimants such as indigents, prisoners, and others without strong employment prospects will be disfavored by the "test of the market." Samuels and Mercuro voice similar concern over Posner's analysis of the case:

What Posner neglects is the fact that the market alone will not determine the prisoner's rights. It is the pre-existing distribution of wealth and power (both a partial function of law) which governs both general prisoner access and also the array of alternative uses of lawyers' services. . . . Establishing a prisoner right to counsel via the market can only be accomplished by accepting other rights and law which govern the flow of legal services. It is much more than mere wealth maximization.

Samuels \& Mercuro, supra note 1, at 122 (footnotes omitted).

${ }^{202}$ See supra notes 74-79 and accompanying text.

${ }^{263}$ See Jackson v. City of Joliet, 715 F.2d 1200 (7th Cir. 1983), cert. denied, 104 S. Ct. 1325 (1984).

201 See LaFalce v. Houston, 712 F.2d 292 (7th Gir. 1983), cert. denied, 104 S. Ct. 712 (1984). Posner argued in that case that the extension of first amendment rights to business firms that are passed over in government contracting because of their political beliefs would result in costs incurred by interference with political patronage. Posner thus concluded that the "desirability of reducing [patronage] . . . raises profound questions of political science that exceed judicial competence to answer . . ." 712 F.2d at 294 . He did note, however, that his opinion was also influenced by his perception that the first amendment interests at stake were "attenuated." Id.

${ }_{288}$ See Sutton v. City of Milwaukee, 672 F.2d 644 (7th Cir. 1982). In upholding the city's policy of towing illegally parked cars in nonemergency situations only if the owner had accumulated two or more unpaid tickets, Posner argued that due process was not violated in part because "[t]he sense of justice is not outraged." Sutton, 672 F.2d at 648 .

${ }^{268}$ See R. POSNER, supra note 22 , at 19-20. 
A major difference between the two disciplines is in their perspectives. Economics takes a top-down approach: it begins with very general hypotheses about human behavior and derives a theory that provides an underlying framework for empirical research. Specific problems are treated by starting with the general theory, adding the variables needed to examine the problem at hand, and then testing the predicted results against observed data. Conversely, traditional jurisprudence takes a bottom-up approach: it begins with specific legal decisions and distills from them the common principles that provide a rational framework for deciding a particular case. Specific problems are treated by starting with their particular facts, identifying the legal issues raised by those facts, and then applying the principles that most analogously cover the facts. ${ }^{287}$ This difference illuminates a significant value of economic analysis of law. Economic analysis can help to build a unified approach to the law by creating cohesive and rational rules applicable across subject areas in place of ad hoc and conflicting rules anchored in sometimes arbitrary or outdated distinctions.

Another difference between economic analysis and traditional jurisprudence is in the contrasting roles that each gives to means and ends. Economics seeks the clear end of efficiency, and focuses on the competitive market system as a viable means of achieving that end. When the market does not work well, economics favors alternative means of attaining efficiency. In contrast, jurisprudence espouses the imprecise end of justice. Because "justice" has no generally accepted meaning, jurisprudence must often rely on legal process in the hope that fair rules will yield legitimate results. ${ }^{268}$ Thus, economic analysis offers an attractive link between means and ends that can be used to enhance the rationality of jurisprudence.

Economics could also strengthen traditional jurisprudence by fostering an approach to legal analysis that treats the determination of the case at bar and the development of legal rules as separate problems. The parties involved in a particular lawsuit are most concerned with distributional issues, while policymakers are preoccupied with the de-

${ }^{267}$ But cf. Posner, supra note 253, at 1115 (noting that, "[g]iven the rapid advances in economic analysis of law, it may be that doctrinal analysts and economic analysts are no longer, as a practical matter, easily separable").

${ }^{268}$ Posner has recognized the importance of legal process in jurisprudence: "The American system of justice has been built on the premise that truth, at least the sort of truth that is relevant to legal rights and remedies, is likeliest to emerge from a vigorously competitive contest between opposing counsel." USM Corp. v. SPS Technologies, Inc., 694 F.2d 505, 509 (7th Cir. 1982), cert. denied, 462 U.S. 1107 (1983). But see Merritt v. Faulkner, 697 F.2d 761, 771 (Posner, J., dissenting) (criticizing the majority's contention that the adversarial system assumes that both parties will have roughly equal legal resources), cert. denied, 104 S. Ct. 434 (1984). 
termination of incentives for future activity. Traditional jurisprudence, however, has united these considerations in its demand for one judicial decision that both determines the case at bar and lays down the rules for the future. Economic analysis could lead the way in rationally assessing this approach.

Thus, economic analysis may play a legitimate role in judicial decisionmaking. The next question, then, is how to effectuate the proper use of economic analysis. Because of the problems of indeterminacy and incompleteness, the role of economics must be to supplement, rather than supplant, traditional legal analysis. An appropriate methodology would consist of four steps: identification, justification, application, and limitation. The first step, identification, is an element already present in most traditional legal analysis: judges often summarize the legal theory. relevant to a given case before applying it to the facts at bar. Thus, judges should clearly identify the use of economics in their opinions. Second, judges should justify the use of economic analysis by identifying the allocational, as opposed to redistributive, issues at stake. Third, judges should apply the theory to the facts of the case. Application will rarely be straightforward; it will involve traditional judicial skills such as line-drawing and commonsense judgment. ${ }^{269}$ Fourth, judges must acknowledge the limitations of the analysis by setting forth the assumptions and reasoning used to derive the legal conclusion from the economic analysis, and by asking whether distributional questions should weigh heavily in the case. ${ }^{270}$

269 "Commonsense judgments" will not always be as helpful as they might seem at first. See, e.g., United States v. Kaminski, 703 F.2d 1004, 1010 (7th Cir. 1983) (Posner, J., concurring). Although Posner provided a legitimate economic rationale for the requirement of predisposition in entrapment doctrine, he did not make the determination of whether predisposition exists any easier than it had been. Despite Posner's contentions, see supra text accompanying note 150, the difference between "psychological conjecture" and "common sense assessment[s]" is not readily apparent. See Samuels \& Mercuro, supra note 1 , at 114 . Even using Posner's economic analysis, a judge must still somehow determine whether the defendant eventually would have committed a crime. See R. TRESCH, supra note 17, at 476:

[G]ost-benefit analysis is as much an art as a science, for which the rule of reason is every bit as important as strict analytical rigor. . . . Consequently, analytical rigor cannot be the sole arbiter in practical policy deliberations. At best these theoretical models provide a consistent analytical framework for thinking about practical problems, with their results serving as guidelines to the policymaker. cases:

270 Posner disputes the contention that distributive questions matter in deciding

Yet even if one believes that distributive considerations must enter into any ultimately acceptable standard of social choice, the courts that administer the liability system might be justified in refusing to allow such considerations to influence the determination of liability. Courts can do very little to 
Finally, improvements of the methodology should be considered. The biggest theoretical disadvantage of economic analysis of law is its failure to postulate any workable theory of political power. Although the prospects of economics developing such a theory in the future are not great, economists could incorporate some of these considerations into their theories. One possibility would be to analyze political power as an economic good. Power is a scarce resource that must be allocated among competing rational actors; therefore, economic theory should be able to say something about it.

\section{CONCLUSION}

Zeal in the application of an innovative methodology should not eradicate careful legal analysis. To the extent that Judge Posner wishes to promote his economic methodology rather than his political ideology, he needs to acknowledge the limitations of the methodology and to wrestle with alternative conceptions of justice. Posner's performance on the bench has demonstrated that economics provides a useful framework for examining legal problems. What he has failed to recognize fully is that the value of economic analysis lies not in the results it enables one to obtain, but rather in the questions it urges one to ask.

affect the determination of wealth in a society ....

Posner, supra note 192, at 132. Posner's justification misses the point. First, courts can affect the distribution of wealth between two individuals involved in a dispute, and many would characterize that activity as "doing justice." Second, although the distribution of wealth between two parties in a dispute may be practically insignificant relative to the distribution of wealth in society, it is symbolically important as evidence of a government's commitment to equity. Finally, if all judges did their fair share of redistributing in appropriate cases, perhaps equity in society would in fact increase. Posner could not personally end the famine in Africa, but would he refrain from making a charitable donation? Or would he conclude that the problem is so large that he as a lone citizen "might as well take it for granted?" Id. at 133. 